University of Nebraska - Lincoln

DigitalCommons@University of Nebraska - Lincoln

USGS Staff -- Published Research

US Geological Survey

2017

\title{
Channel-planform evolution in four rivers of Olympic National Park, Washington, USA: the roles of physical drivers and trophic cascades
}

Amy E. East

US Geological Survey, aeast@usgs.gov

Kurt J. Jenkins

US Geological Survey

Patricia J. Happe

National Park Service

Jennifer A. Bountry

Sedimentation and River Hydraulics Group

Timothy J. Beechie

National Marine Fisheries Service

See next page for additional authors

Follow this and additional works at: http://digitalcommons.unl.edu/usgsstaffpub

Part of the Geology Commons, Oceanography and Atmospheric Sciences and Meteorology Commons, Other Earth Sciences Commons, and the Other Environmental Sciences Commons

East, Amy E.; Jenkins, Kurt J.; Happe, Patricia J.; Bountry, Jennifer A.; Beechie, Timothy J.; Mastin, Mark C.; Sankey, Joel B.; and Randle, Timothy J., "Channel-planform evolution in four rivers of Olympic National Park, Washington, USA: the roles of physical drivers and trophic cascades" (2017). USGS Staff -- Published Research. 1010.

http://digitalcommons.unl.edu/usgsstaffpub/1010

This Article is brought to you for free and open access by the US Geological Survey at DigitalCommons@University of Nebraska - Lincoln. It has been accepted for inclusion in USGS Staff -- Published Research by an authorized administrator of DigitalCommons@University of Nebraska - Lincoln. 
Authors

Amy E. East, Kurt J. Jenkins, Patricia J. Happe, Jennifer A. Bountry, Timothy J. Beechie, Mark C. Mastin, Joel B. Sankey, and Timothy J. Randle 


\title{
Channel-planform evolution in four rivers of Olympic National Park, Washington, USA: the roles of physical drivers and trophic cascades
}

\author{
Amy E. East, ${ }^{1 *}$ Kurt J. Jenkins, ${ }^{2}$ Patricia J. Happe, ${ }^{3}$ Jennifer A. Bountry, ${ }^{4}$ Timothy J. Beechie, ${ }^{5}$ Mark C. Mastin, ${ }^{6}$ Joel B. Sankey $^{7}$ and \\ Timothy J. Randle ${ }^{4}$ \\ ${ }^{1}$ US Geological Survey, Pacific Coastal and Marine Science Center, Santa Cruz, CA 95060, USA \\ 2 US Geological Survey, Forest and Rangeland Ecosystem Science Center, Olympic Field Station, Port Angeles, WA 98362, USA \\ ${ }^{3}$ National Park Service, Olympic National Park, Port Angeles, WA 98362, USA \\ ${ }^{4}$ Bureau of Reclamation, Sedimentation and River Hydraulics Group, Denver, CO 80225, USA \\ ${ }^{5}$ National Marine Fisheries Service, National Oceanic and Atmospheric Administration, Seattle, WA 98112, USA \\ ${ }^{6}$ US Geological Survey, Washington Water Science Center, Tacoma, WA 98402 \\ 7 US Geological Survey, Southwest Biological Science Center, Flagstaff, AZ 86001, USA
}

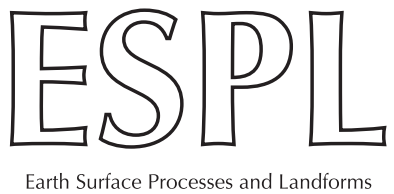

ABSTRACT: Identifying the relative contributions of physical and ecological processes to channel evolution remains a substantial challenge in fluvial geomorphology. We use a 74-year aerial photographic record of the Hoh, Queets, Quinault, and Elwha Rivers, Olympic National Park, Washington, USA, to investigate whether physical or trophic-cascade-driven ecological factors - excessive elk impacts after wolves were extirpated a century ago - are the dominant drivers of channel planform in these gravel-bed rivers. We find that channel width and braiding show strong relationships with recent flood history. All four rivers widened significantly after having been relatively narrow in the 1970s, consistent with increased flood activity since then. Channel planform also reflects sediment-supply changes, evident from landslide response on the Elwha River. We surmise that the Hoh River, which shows a multi-decadal trend toward greater braiding, is adjusting to increased sediment supply associated with rapid glacial retreat. These rivers demonstrate transmission of climatic signals through relatively short sediment-routing systems that lack substantial buffering by sediment storage. Legacy effects of anthropogenic modification likely also affect the Quinault River planform.

We infer no correspondence between channel evolution and elk abundance, suggesting that trophic-cascade effects in this setting are subsidiary to physical controls on channel morphology. Our findings differ from previous interpretations of Olympic National Park fluvial dynamics and contrast with the classic example of Yellowstone National Park, where legacy effects of elk overuse are apparent in channel morphology; we attribute these differences to hydrologic regime and large-wood availability. Published 2016. This article is a U.S. Government work and is in the public domain in the USA

KEYWORDS: fluvial geomorphology; channel evolution; trophic cascades; glacier retreat; climate signal

\section{Introduction}

The relative roles of hydrology, sediment supply, and ecological factors in controlling river-channel dynamics remain incompletely understood, even after decades of rapid advances in fluvial geomorphology (Phillips, 1995; Tal et al., 2004; Church, 2010; Reinhardt et al., 2010; Constantine et al., 2014; Corenblit et al., 2015; Gran et al., 2015). Many researchers have attempted to identify the dominant influences on channel planform in alluvial rivers; most such field studies focus on systems affected by anthropogenic land use and flow manipulation (Smith and Smith, 1984; Chien, 1985; Everitt, 1993; Madej and Ozaki, 1996; Simon et al., 2002; Rinaldi, 2003; Gendaszek et al., 2012; Heitmuller, 2014; Caskey et al., 2015; Rhoads et al., 2016). In contrast to the more abundant literature on river response to factors such as dams, urbanization, and deforestation, this study addressed channel evolution in the Olympic Peninsula, Pacific Northwest, USA, where glaciated, forested alpine watersheds are relatively unaffected by direct human influence.

Even in a region protected or managed as wilderness, rivers can change substantially on decadal and shorter time scales, driven by natural variability and human influence on climate and ecosystems. Understanding fluvial geomorphic evolution is particularly critical in alpine watersheds, given their great sensitivity to climatic changes (Davies et al., 2001; Brocklehurst and Whipple, 2002; Ballantyne et al., 2014; Micheletti et al., 2015; Micheletti and Lane, 2016; Schildgen et al., 2016). Although precipitation and temperature are known to drive runoff and sediment production from high mountain catchments, the degree to which these climatic signals propagate downstream rather than being buffered by 
sediment storage and autogenic channel dynamics remains less clear (Castelltort and Van Den Driessche, 2003; Simpson and Castelltort, 2012; Armitage et al., 2013; Blöthe and Korup, 2013; Phillips and Jerolmack, 2016).

Among the many ways in which ecological factors and feedbacks can influence fluvial landscapes (Reinhardt et al., 2010; Gurnell, 2014), some of the most intriguing and far-reaching involve trophic cascades. Documentation of top-down terrestrial and marine trophic cascades - wherein removal of top (apex) predators leads to increased mesopredator and herbivore abundance, and the latter affect myriad ecosystem properties through intensive herbivory - represented milestones in ecological research of the past few decades (Leopold, 1949; Estes et al., 1998, 2011; Schmitz et al., 2000; Terborgh et al., 2001; Prugh et al., 2009). Terrestrial trophic cascades occur over biogeographically diverse regions of western North America (see summary by Eisenberg, 2011). Many such studies have been conducted in national parks, where other anthropogenic influence is muted enough to facilitate detection of changes in herbivore abundance after predator loss or reintroduction, as well as associated behavioral changes in browsing intensity and site preference (the 'ecology of fear'; Ripple and Beschta, 2006; Eisenberg, 2011).

Following the premise that channel form and mobility can change as a result of riparian vegetation growth or loss (Graf, 1978; Hupp and Osterkamp, 1996; Allmendinger et al., 2005; Gurnell, 2014; Corenblit et al., 2015), several recent studies have made significant advances by linking trophic-cascades concepts to geomorphology. The classic example of a trophic cascade affecting landscapes relates to riparian vegetation and channel changes associated with wolf-elk interactions in Yellowstone National Park (YNP, in Montana, Wyoming, and Idaho, USA; Ripple and Beschta, 2004a, 2012; Beschta and Ripple, 2006, 2007, 2010, 2012; Marshall et al., 2013; Painter et al., 2015). Many decades after wolf extirpation from YNP and several years after wolf reintroduction in 1995, Beschta and Ripple (2006) identified continuing legacy effects from an early-twentieth-century elk-population increase that followed wolf extirpation. Geomorphic effects in YNP of abundant elk 80 years earlier, triggered by intensive browsing of streamside vegetation and riverbank trampling, were inferred to include channel widening, incision, and hydrologic disconnection between channel and floodplain (Beschta and Ripple, 2006).

The rivers of Olympic National Park (ONP; Figure 1) have been identified recently as another example of top-down trophic cascades affecting fluvial systems (Beschta and Ripple, 2008, 2012; Eisenberg, 2011). Beschta and Ripple (2008) proposed that river morphology in ONP responds primarily to ecological dynamics comprising a wolf-elk-driven trophic cascade. They identified legacy effects in ONP attributed to early-twentieth-century wolf extirpation and subsequent elk population increase, including (1) changes to vegetation assemblages, i.e. decreased recruitment of black cottonwood (Populus balsamifera trichocarpa) and bigleaf maple (Acer macrophyllum) trees; and (2) widening of ONP rivers and a transition from single-thread to braided morphology. The latter findings were based on a comparison of modern channel planform in three river reaches inside ONP (on the Hoh, Queets, and East Fork Quinault Rivers) with two reaches outside ONP (west of the park, on the Clearwater and lower Quinault Rivers),

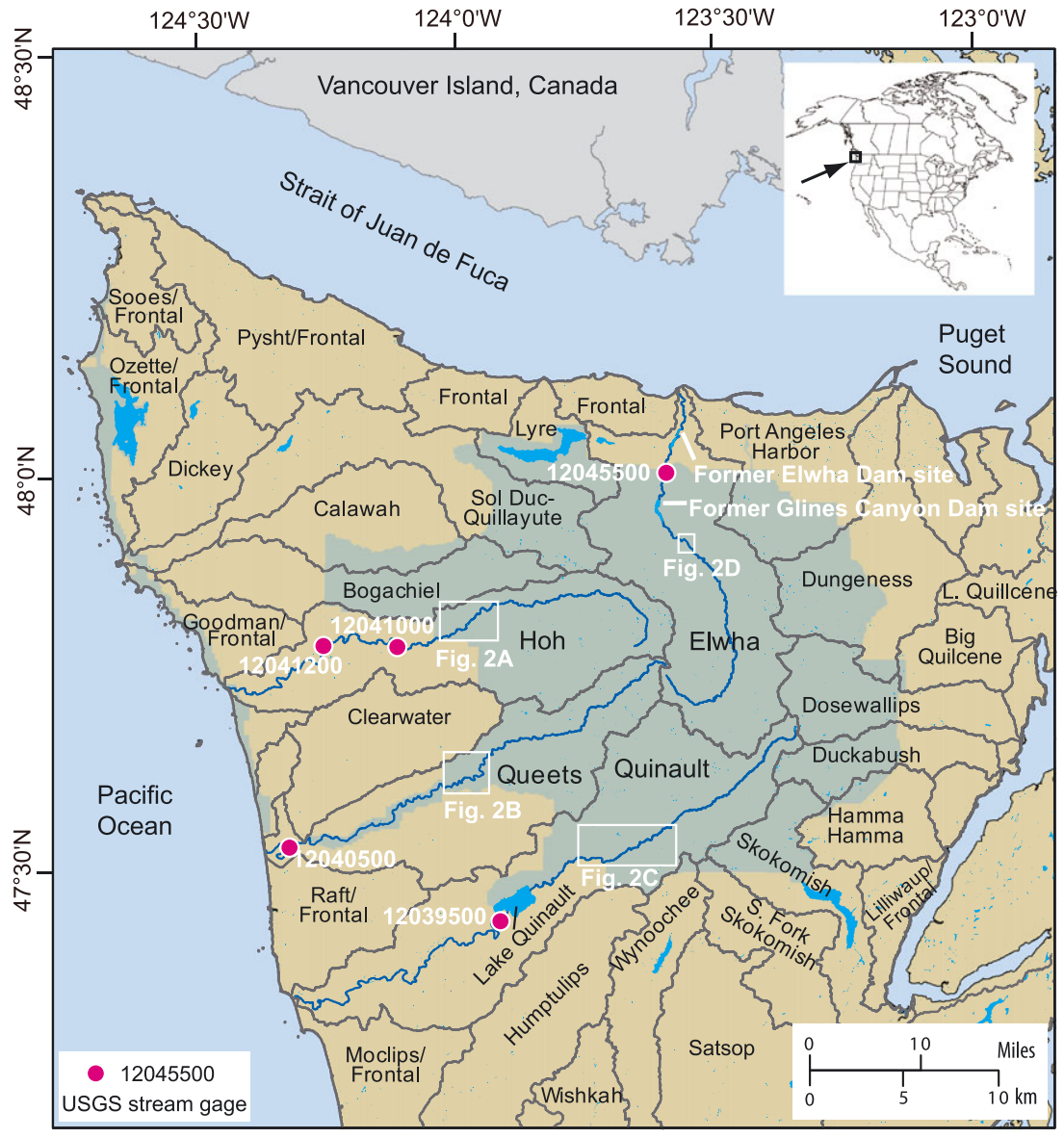

Figure 1. The Olympic Peninsula, Washington, USA. Green area shows modern extent of Olympic National Park (ONP); the Olympic Mountains occupy the central portion of ONP. Dark lines indicate watershed boundaries; for clarity, river channels are shown only for the mainstem Hoh, Queets, Quinault, and Elwha Rivers. White boxes indicate study reaches shown in Figure 2. 'Frontal' refers to small, unnamed watersheds that drain directly to the coast. 
and the assumption that spatial differences in river morphology were caused by greater elk density within ONP, where elk are protected from hunting. Beschta and Ripple (2008) also noted that early settlers described the upper Quinault River as narrow and vegetated, in contrast to its wider, less vegetated modern state. They inferred that the wide, braided channels present today in some ONP watersheds developed due to channel instability initiated by wolf removal and intensive vegetation browsing by a large elk population in the early 1900 s.

We investigated physical and ecological drivers of channel evolution in ONP. We hypothesized that river discharge drives channel morphology on these rivers - that greater flow magnitude (especially flood peaks) would correspond to greater width and braiding. To test this hypothesis, we evaluated statistical correspondence between channel planform in selected reaches of the Hoh, Queets, Quinault, and Elwha Rivers (analyzed using a 74-year aerial-photographic record) and discharge records from those rivers. We also investigated an alternative hypothesis that elk abundance may drive channel width and braiding. Thus, we reassessed all previous ONP elk-population estimates and evaluated whether greater elk abundance indeed corresponded to wider, more braided rivers. We have not addressed all components of the trophic-cascade hypothesis, e.g. that changes in river planform are associated temporally with changes in riparian vegetation density and assemblage, as detailed vegetation-change data are largely unavailable. Previous research identifying elk herbivory as a primary control on vegetation composition and structure in these floodplain forests supports our use of elk abundance as a key feature of the trophic cascade (Happe, 1993; Woodward et al., 1994; Schreiner et al., 1996).

We also considered such evidence as is available on channel response to sediment-supply changes and human alteration (where aerial imagery or previous field studies suggested these factors were important), although we do not have quantitative, time-series data to assess sediment-load history or direct anthropogenic effects in detail. We used stage-discharge records from each river to assess evidence for system-wide bed aggradation in the early 1900s; if river reaches upstream of the stream-gage sites had undergone a major widening and transition from single-thread to braided then, as Beschta and Ripple (2008) proposed, a substantial fluvial sediment pulse likely would have occurred (Jacobson and Gran, 1999) that should have been evident in the stage-discharge history.

\section{Study Area}

The Olympic Peninsula in northwest Washington comprises steep, mountainous terrain within the forearc high of the Cascadia subduction zone (Figure 1; Brandon et al., 1998; Stewart and Brandon, 2004). Watersheds of the Olympic Mountains (reaching elevations $>2400 \mathrm{~m}$ in the center of the peninsula) contain Neogene metasedimentary rocks, basalts and basaltic breccias of the ophiolitic Coast Range terrane, and Quaternary alpine glacial outwash and glaciolacustrine deposits (Tabor and Cady, 1978; Brandon et al., 1998; Gerstel and Lingley, 2003). On the western side of the Olympic Peninsula, where westerly or southwesterly Pacific storms intersect the Olympic Mountains, precipitation ranges from $3440 \mathrm{~mm} / \mathrm{yr}$ in the lowlands to $7900 \mathrm{~mm} / \mathrm{yr}$ in the central mountains (PRISM, 2016). Rapid uplift rates, steep slopes, abundant rainfall that promotes landsliding, and active glaciation (184 alpine glaciers as of 2009; Riedel et al., 2015) contribute to high sediment yield from watersheds that drain the central Olympic Peninsula (cf. Milliman and Farnsworth, 2011). The rivers also recruit sediment from relict glacial and proglacial deposits in bluffs, terraces and floodplains (O'Connor et al., 2003; Kloehn et al., 2008; Draut et al., 2011).

The regional hydrologic regime includes a spring snowmelt season (May-July), and a winter-storm season (NovemberMarch) during which most flood peaks occur. Winter floods, including large rain-on-snow events, often disturb river channels substantially. The lowest annual flows occur in September. Flood magnitude typically fluctuates over decadal scales, due in part to Pacific Decadal Oscillation (PDO) cycles (Mantua et al., 1997; Czuba et al., 2012). Flood magnitude and frequency generally have been greater in Pacific Northwest rivers since the late 1970s than over the period of record as a whole (Piety et al., 2004; Bountry et al., 2005; Beschta and Ripple, 2008; Czuba et al., 2012; Tohver et al., 2014).

In Olympic Peninsula rivers, as elsewhere throughout the coastal Pacific Northwest, large woody debris plays a key role in channel and floodplain evolution. Woody debris commonly controls the locations of sediment deposition and channelavulsion nodes; sediment-wood feedbacks contribute to channel complexity and to highly productive aquatic and riparian ecosystems (Swanson and Lienkaemper, 1982; Bilby and Ward, 1991; Fetherston et al., 1995; Abbe and Montgomery, 1996, 2003; Collins et al., 2002, 2012; Beechie et al., 2006; Latterell et al., 2006; Van Pelt et al., 2006; Latterell and Naiman, 2007; Naiman et al., 2010; Wohl, 2013).

Human modification of the Olympic Peninsula intensified after Euro-Americans arrived in the 1790s and settled in increasing numbers during the late 1800s. Direct human impact on forests and rivers in the central peninsula includes limited numbers of homestead parcels founded in the late 1800s and early 1900s, roads and minor infrastructure along parts of river corridors (no roads cross the Olympic Mountains), and in the early 1900s, logjam and tree removal and bank modification, especially on the Quinault River (Bountry et al., 2005). The central part of the peninsula was designated to remain undeveloped first as Olympic National Monument in 1909, then as Olympic National Park (ONP) in 1938 - to protect Roosevelt elk (Cervus elaphus roosevelti), the dominant large mammalian herbivore of this region (Jenkins and Starkey, 1984; Houston et al., 1990), as well as the most primeval examples of Pacific Northwest riverine and forested ecosystems. Although the park boundaries have shifted several times since protected status began, old-growth forest remains over most of the modern park area (Figure 1). Wildfires and large wind events modify these forests infrequently but catastrophically (Agee, 1993). Clearcut logging, peaking in the 1950s-1980s, converted large areas of late-seral forest to younger forest along the park perimeter and in adjacent lowlands.

Increasing human pressure from land use and hunting in the late 1800s and early 1900s shifted populations of several large mammal species on the Olympic Peninsula. A predator-bounty incentive decreased the number of cougars (Puma concolor) and led to regional extirpation of wolves (Canis lupus) by the 1920s (Scheffer, 1995). Humans also extensively hunted Roosevelt elk, a common prey of wolves; by 1905, elk populations had fallen low enough to warrant a hunting moratorium. Responding both to the 28-year ban on legal hunting and to wolf removal, the elk population on the peninsula increased rapidly in the 1910s, peaking in the mid-1930s (A. Murie, 1935a; Beschta and Ripple, 2008). Contemporaneous accounts reported that excessive herbivory by elk had reduced vegetation on key winter elk ranges within ONP (Sumner, 1938). Elk influence on vegetation in the 1930s included intensive and spatially extensive browsing pressure and decreased recruitment of favored browse species, including black cottonwood and bigleaf maple (O.J. Murie, 1935b), which today are present in riparian forest overstory but generally absent in the 
understory (Van Pelt et al., 2006; Beschta and Ripple, 2008). The tendency of elk to affect vegetation structure and community composition in ONP river corridors (Schwartz, 1939; Newman, 1954; Happe, 1993; Woodward et al., 1994; Schreiner et al., 1996), together with their population increase following wolf extirpation, formed the premise of the Beschta and Ripple (2008) conceptual model in which these influences led to wider, more braided river channels.

\section{Methods}

\section{Reach-based planform analysis from aerial imagery}

We quantified channel planform along one study reach on each of the Hoh, Queets, Quinault, and Elwha Rivers (Figures 1-3) that are largely protected as wilderness. These alluvial study reaches comprise braided and island-braided gravel-bed rivers within the plane-bed and pool-riffle classes of Montgomery and Buffington (1997). Each reach has numerous side channels visible in aerial photographs (Figure 3), although field examination reveals additional inactive or minimally wetted channels not visible from the air (cf. Van Pelt et al., 2006; Konrad, 2012). Reaches extended as far as possible without substantial spatial changes in discharge or sediment supply (e.g. without large tributary confluences) and with little to no human land use. All of the study reaches correspond to primary elk ranges (Jenkins and Starkey, 1984; Houston et al., 1990; Schroer et al., 1993).

The Hoh River study reach was $10 \mathrm{~km}$ long (Figure 2(A)), with a gradient of 0.0056 ; we analyzed 10 sets of aerial images showing this unconfined alluvial reach (Figure 4(A); Supplementary material, Table A1). The Queets River reach was $10 \mathrm{~km}$ long, including a $2.5-\mathrm{km}$-long segment that is confined such that the active flow zone is approximately one-third the width in the unconfined section (transects 23-32; Figure 2(B)). The gradient throughout the $10-\mathrm{km}$ Queets reach is 0.0042 ; we analyzed eight sets of aerial images of this reach (Figure 4 (B); Table A2). The Quinault River reach was $6.25 \mathrm{~km}$ long along an unconfined alluvial portion of the mainstem river with a gradient of 0.0045 (Figure $2(\mathrm{C})$ ), from which we analyzed 11 sets of aerial images (Figure 4(C); Table A3). The left bank of the Quinault River is outside Olympic National Park, and portions of the right bank were not part of protected lands between 1915 and 1943. Therefore, the Quinault reach has had more anthropogenic influence than the other three in our study - logging, logjam removal, and bank modification - at times and places not well documented (Bountry et al., 2005). However, no logging was evident along or upslope from the study reach during the time covered by the aerial photographic record. The Elwha River study reach, $3.25 \mathrm{~km}$ long with a gradient of 0.0166 (Figure 2(D)), was upstream from the sites of two former dams and reservoirs that were removed between 2011 and 2014 (East et al., 2015a). Backwater effects from the upper reservoir did not extend far enough upstream to affect our study reach (Randle et al., 2015). We analyzed nine sets of aerial images of the Elwha reach (Figure 4(D); Table A4).

We analyzed channel planform in each of the four reaches using a 74-year record of aerial imagery (1939-2013), comprising aerial photographs that were either orthoimages or that had been georeferenced using ground-control points (Supplementary material, Appendix). For georeferenced images we estimated spatial uncertainty by comparing the positions of photoidentifiable features with those in the 2013 orthoimages, and adding the average of the offsets to the $5 \mathrm{~m}$ horizontal uncertainty of the 2013 orthoimagery. In addition, we assumed a $3 \mathrm{~m}$ digitizing error (inaccuracy in identifying locations of interest) arising from shadows of trees and steep banks. We estimated total spatial uncertainty by summing these independent values in quadrature for each set of images (A1-A4; Gaeuman et al., 2003; Hapke and Reid, 2007).

We digitized the margins of the recently active flow zone on each set of photographs using $\operatorname{ArcGIS}^{\mathrm{TM}}$, assuming that the unvegetated portion of the floodplain had been occupied recently by flow (Sear et al., 1995; Kondolf et al., 2002), as vegetation would rapidly colonize riparian areas that are not locations of active flow (cf. O'Connor et al., 2003; Cadol et al., 2011; Konrad, 2012). If the recently active flow zone
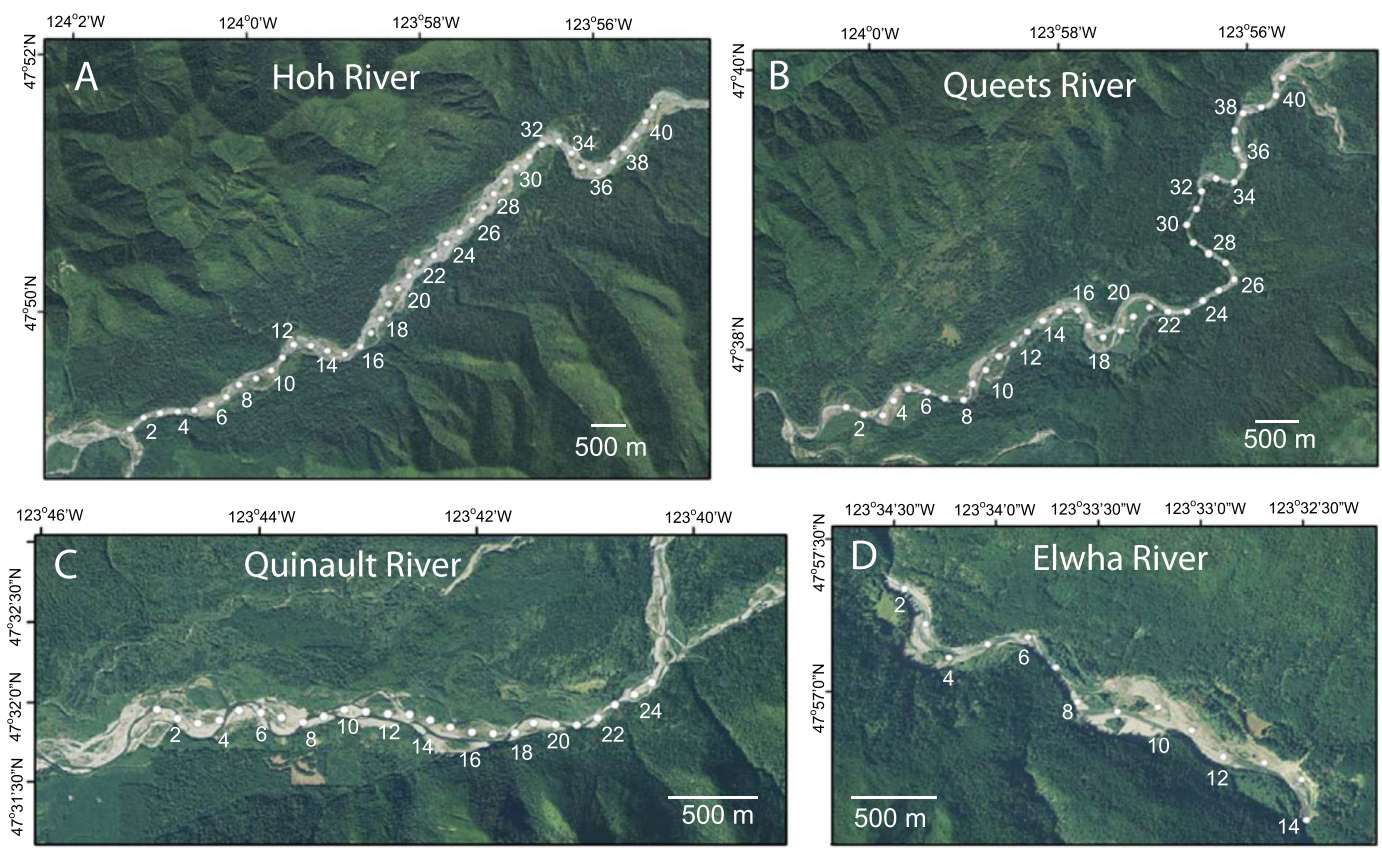

Figure 2. Aerial orthoimages of study reaches on the (A) Hoh River, reach length $10 \mathrm{~km}$; (B) Queets River, reach length $10 \mathrm{~km}$; (C) Quinault River, reach length $6.25 \mathrm{~km}$; (D) Elwha River, reach length $3.25 \mathrm{~km}$. Images are from summer 2013 (US Department of Agriculture, 2013). White circles show points $250 \mathrm{~m}$ apart established in ArcGIS and used to assign transect locations on these and all other sets of aerial photographs for each reach. For clarity, only even-numbered points are labeled. 

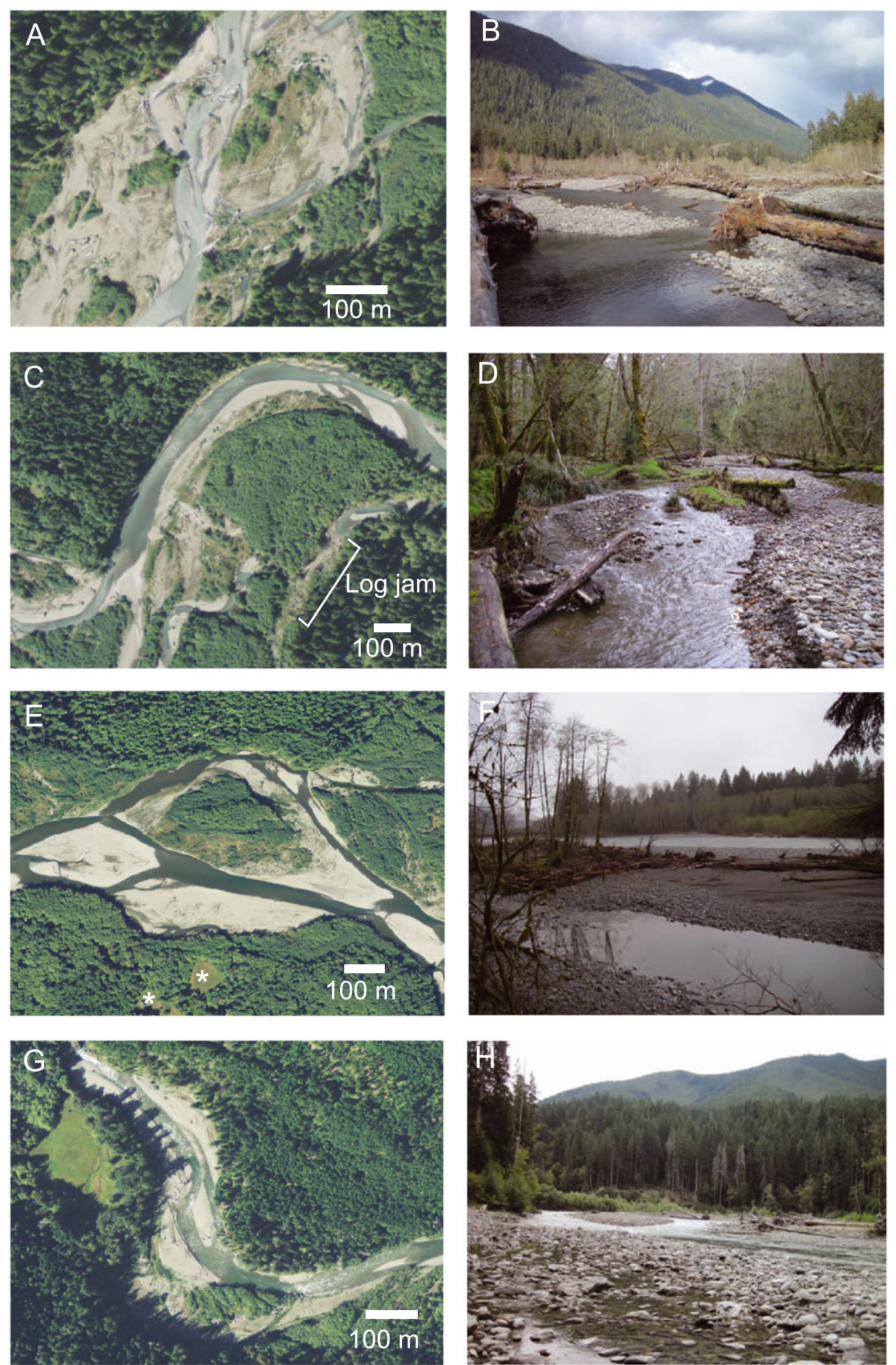

Figure 3. Aerial and oblique photographs showing representative morphology of study reaches. (A) Hoh River in the vicinity of transect (T) 28 , summer 2013. (B) Hoh River near T33, summer 2011. (C) Queets River in the vicinity of T18-21, summer 2013; note large logjam filling side channel. (D) Side channel in the Queets River floodplain, spring 2007. (E) Quinault River in the vicinity of T11-13, summer 2013. Asterisks indicate anthropogenic clearings on river left, outside the ONP boundary. (F) Quinault River, spring 2007. (G) Elwha River in the vicinity of T1-4, summer 2013. Large meadow is a natural feature. (H) Elwha River at T2, summer 2012. Aerial images from National Aerial Imaging Program (US Dept. of Agriculture, 2013), field photographs by A. East.

included a wetted braid separated from the rest of the (unvegetated) floodplain by vegetated, forested floodplain, we included the forested island within the active zone. We also digitized midlines of the mainstem (the widest channel) and any braids (wetted channels with surface-water connection to the mainstem). Interpretation of braids depends upon the flow at the time of photography, but we assume this had little effect on our analysis because almost all photographs represent summer low flow (A1-A4). On the 1939 images of the Elwha River, we were unable to analyze braids due to low photographic resolution; however, we did identify unvegetated channel margins.

Along each study reach we established fixed points $250 \mathrm{~m}$ apart in the center of the 2013 active floodplain (Figure 2), and then established transects at those points on each set of images for that river. We oriented transects orthogonal to the 


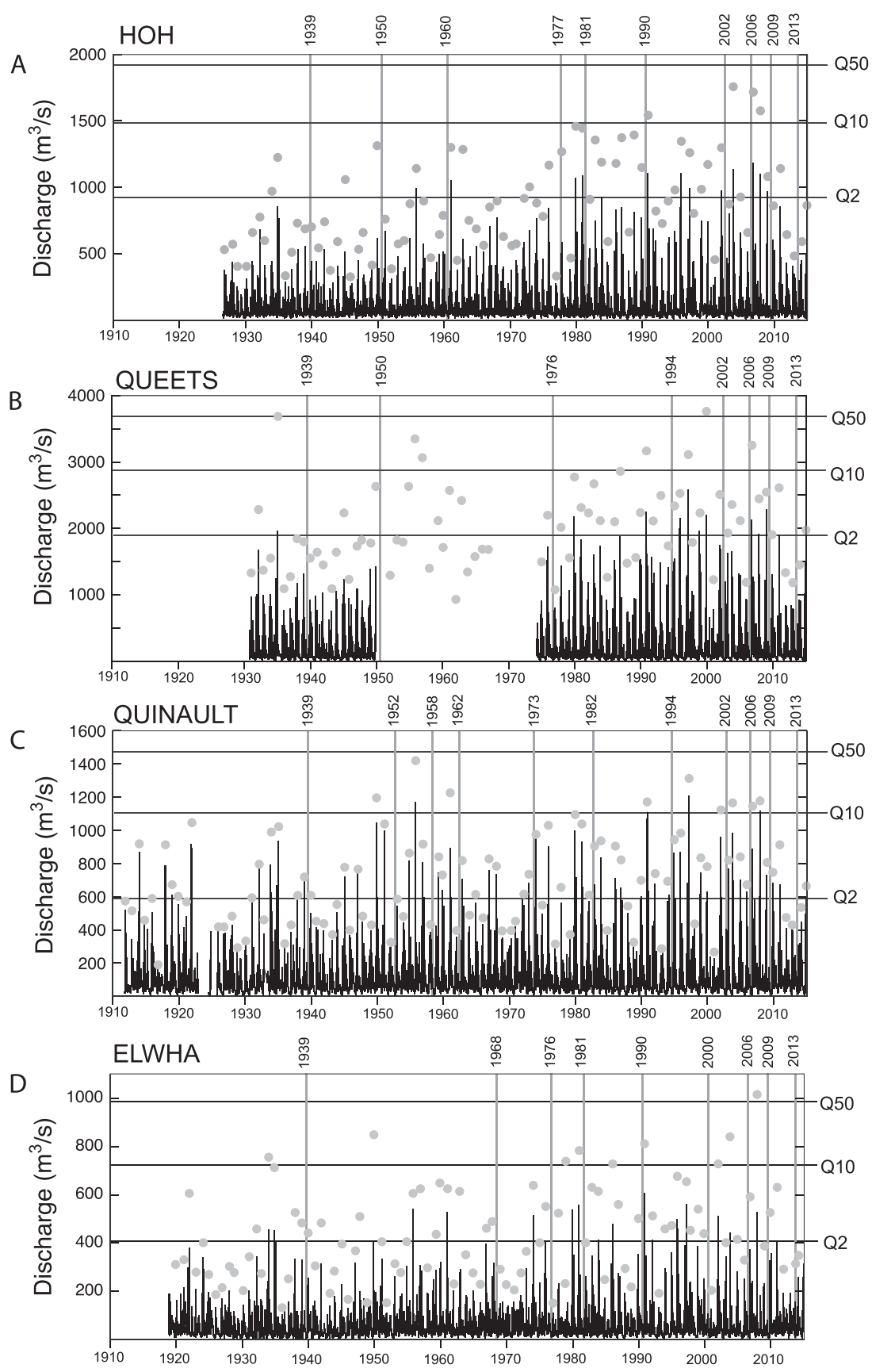

Figure 4. Hydrographs for the period of record for the (A) Hoh River, at USGS gaging stations 12041000 and 12041200 (see Appendix for explanation of combined gage records); (B) Queets River, at USGS gaging station 12040500; (C) Quinault River, at USGS gaging station 12039500; and (D) Elwha River, at USGS gaging station 12045500. Stream-gage locations are shown on Figure 1. Black lines show daily average discharge; gray circles show instantaneous annual peak flow values. Horizontal lines Q2, Q10, and Q50 indicate peak-flow magnitudes with 2, 10, and 50-year recurrence intervals, respectively, calculated using log-Pearson type III flood-frequency analyses for the period of record for each gage, up through and including water-year 2014 (30 September 2014). Vertical gray lines show years from which we analyzed aerial photographs.

active river corridor; thus, transect alignment varied slightly between photograph sets as the orientation of the active river corridor varied. On each transect we measured the active width (distance between left and right margins of the recently active flow zone), and recorded the number of braids that the transect crossed.

We calculated two types of channel braiding index: the length-based index of Friend and Sinha (1993; the sum of the lengths of all channels, divided by the length of the mainstem), and the number-based index of Howard et al. (1970; the mean number of channels that transects cross). Of the many ways to assess channel braiding (Egozi and Ashmore, 2008), we selected these because they independently assess different aspects of braiding (total sinuosity vs. intensity of flow division). Number-based indices are used more commonly, but the
Friend and Sinha (1993) method incorporates information about places that transects do not happen to cross.

For additional information on channel morphology prior to 1939, we examined General Land Office (GLO) cadastral maps from the early 1900s (Bureau of Land Management, 2016). We also examined descriptions and images from early explorer accounts relating to river morphology (Wood, 1967; Morganroth, 1991 ; Lien, 2001; Jefferson County Historical Society, 2010; Washington State Library, 2015). We could not verify that early surveyors or explorers defined the active river corridor with criteria similar to ours, nor whether they identified all channel braids present then. Early maps show river-corridor margins but only some maps show braids, even though survey notes mentioned crossing multiple channels and islands. Early maps also used variable standards for delineating channel margins, 
with some demarcating 'mean high-water elevation' and others showing only the low-flow channel (O'Connor et al., 2003). Some early surveys show channel margins that appear geomorphically unrealistic (Bountry et al., 2005), and some recorded channel width along section boundaries of the township-and-range grid that were oblique to the river-corridor orientation, yielding wider values than would orthogonal measurements. Thus, we consulted these records to inform our understanding of historical variability, but did not compare them directly with the detailed analyses from aerial photography.

\section{Analysis of discharge records}

We compared aerial photographic records of channel planform to the hydrographs for each river measured at US Geological Survey (USGS) stream gages (http://waterdata.usgs.gov/nwis/; Figure 4). Discharge recorded at the gages is higher than in the respective study reaches because ungaged tributaries enter the mainstem rivers below the study reaches but above the gage sites (Figure 1). However, the hydrographs can be used to resolve seasonal and interannual flow variability and to identify approximate recurrence intervals of high flows.

To assess decadal-scale changes in flood regime, we calculated Q2 values (two-year-flood magnitude, commonly assumed to represent bankfull discharge) using log Pearson III flood-frequency analyses of annual flood peaks (US Geological Survey, 1981) for various time intervals of interest. We also calculated Q2 values throughout the record length for each river using a 15-year moving window, to assess temporal changes in flood magnitude.

We analyzed stage-discharge history from 1950 and earlier at each gage site, to determine whether major bed-elevation changes had occurred that might represent a system-wide sediment pulse in the early twentieth century associated with channel widening and a transition from single-thread to braided morphology. We focused in particular on the time before 1939, corresponding to peak elk population (Beschta and Ripple, 2008) and preceding aerial photographic records. Early stage-discharge rating curves were not well defined at high stages, due to a lack of discharge measurements during high flows. For this reason, we selected a discharge with 1-1.5-year peak return interval, for which rating curves were reasonably well defined, and obtained the corresponding stage (water-surface elevation) from each stage-discharge rating curve. Stage differences would represent scour or fill on the hydrauliccontrol feature, such as a riffle, that determines stage at the gage site.

\section{Elk-population estimates}

We assessed temporal changes in elk population within ONP by compiling and reanalyzing all known historical estimates from published literature, unpublished agency reports and memoranda, and field data. Elk numbers and distribution prior to Euro-American settlement are unknown, other than that early settlers considered elk abundant (Skinner, 1933; Wood, 1967). Population estimates in the early twentieth century were essentially informed guesses, based on interviews with local residents and US Forest Service managers (Lovejoy, 1911; Fromme, 1915). In the 1930s and 1950s population estimates were based on extensive field reconnaissance of key elk ranges by US Forest Service and National Park Service (NPS) biologists (A. Murie, 1935a; O.J. Murie, 1935b; Schwartz, 1939; Newman, 1954). Since the 1980s, elk abundance has been estimated based on aerial surveys and field surveys of fecal pellets (Houston et al., 1990; Jenkins and Manly, 2008).

Elk that inhabit the eastern and southern Olympic Mountains migrate annually to winter ranges outside the ONP boundaries, whereas elk from the Elwha watershed west and south through the Sol Duc, Calawah, Bogachiel, Hoh, Queets, and Quinault Rivers (Figure 1) generally live within ONP year round (Houston et al., 1990). Thus, to evaluate the most representative parkwide temporal changes in elk population, we examined estimates of elk abundance collectively in these seven watersheds, which correspond not only to the primary yearround ONP elk population but also to the north-south extent of river reaches in which we studied planform change.

Elk populations along the Hoh and Queets Rivers have been surveyed repeatedly by helicopter between 1985 and 2010 (Houston et al., 1987; Jenkins et al., 2015), allowing more detailed assessment of elk-population trends within those two river corridors. Aerial surveys occurred during early spring, after elk concentrated in deciduous or open-canopied forests to feed on new herbaceous vegetation growth, but before deciduous trees leafed out and obscured an aerial view (Jenkins and Starkey, 1984; Houston et al., 1987). Three observers and a pilot counted all elk seen from a helicopter flown slowly $(\sim 55 \mathrm{~km} / \mathrm{h})$ at 100-200 $\mathrm{m}$ above the ground, following parallel transects 200-300 m apart. Flights paths covered valley floors (glacial and fluvial terraces and floodplains), and permitted easy identification of duplicate observations from adjacent transects. We report raw counts of elk as well as predicted counts that factor in environmental variables affecting the number of elk in the survey area (Jenkins, 1980): the survey date, minimum temperature on the morning of the survey, and the cumulative number of growing degree days $\left(>4.4^{\circ} \mathrm{C}\right)$ preceding the survey, measured from 1 February. We used these variables to adjust the field-survey estimates according to the model of Jenkins et al. (2015).

We calculated the exponential rate of population change for the year-round ONP elk population (in the Elwha, Sol Duc, Calawah, Bogachiel, Hoh, Queets, and Quinault watersheds) from 1937 to 2002 (dates of elk counts that most closely match the temporal span of the aerial photographic record), and for the Hoh and Queets valleys from 1985 to 2010. The exponential rate of population change, $r$, is simply the slope parameter for the linear regression of the natural logarithm of elk numbers against time (Caughley and Birch, 1971).

\section{Statistical analyses}

We examined statistical relationships between channel morphology and flood history, mean-annual-flow history, and elk abundance using generalized linear models. We represented channel width in each set of aerial images as the reachaveraged width from that photograph set normalized by the mean width over the entire aerial-image record for that river. We represented channel braiding similarly, using the Friend and Sinha (1993) braiding index normalized by the mean value for the entire aerial-image record for each river, respectively. To represent recent flood activity we used the largest flood peak in the 8 years preceding each set of aerial images, normalized by the Q2 magnitude for each river, respectively. The 8-year duration was chosen because visual examination of photographic records suggested that large floods can still be evident in channel morphology after that time, but not necessarily much longer. To represent recent mean flow history, we used the mean annual flow for the 8 years preceding each set of photographs normalized by the mean annual flow for the entire period of record for each river. Because elk-population estimates are from 
different years to the aerial photographs on which we measured channel planform, we interpolated elk abundance for the years of aerial photography using linear regression of the natural logarithm of park-wide elk population. We used park-wide estimates of elk abundance because watershed-specific data are more limited in spatial and temporal scope, as discussed above.

We examined the effects of model parameters FLOOD (8-year peak divided by Q2), MAF (8-year mean annual flow divided by whole-record mean), ELK (interpolated elk abundance divided by the 1939-2013 mean of interpolated abundance), FLOOD + ELK, and MAF + ELK on channel width and braiding, as well as a NULL model representing no change in planform over time. For each metric we used the Akaike Information Criterion for small sample size $\left(\mathrm{AIC}_{C} ;\right.$ Akaike, 1974) and $\Delta \mathrm{AIC}_{C}$ to evaluate relative support for competing models, where $\triangle \mathrm{AIC}_{C}$ is the difference between $\mathrm{AIC}_{C}$ for a given model and the model with the smallest $\mathrm{AIC}_{C}$. We considered models with $\Delta \mathrm{AIC}_{C}<2$ to be highly supported, models with $4<\Delta \mathrm{AIC}_{C}<7$ to be considerably less supported, and models with $\Delta \mathrm{AIC}_{C}>10$ to have essentially no support (Burnham and Anderson, 2002; Sankey et al., 2015). Models that did not differ from the null model by more than 10 $\mathrm{AIC}_{c}$ units were also considered to have no support.

\section{Results}

\section{Channel-planform evolution}

Our geospatial analyses showed substantial spatial and temporal variation in channel width and braiding along the Hoh, Queets, Quinault, and Elwha Rivers between 1939 and 2013 (Figures 5-7; Supp. Appendix). At any point in time represented in the aerial photographic record, the width of the recently

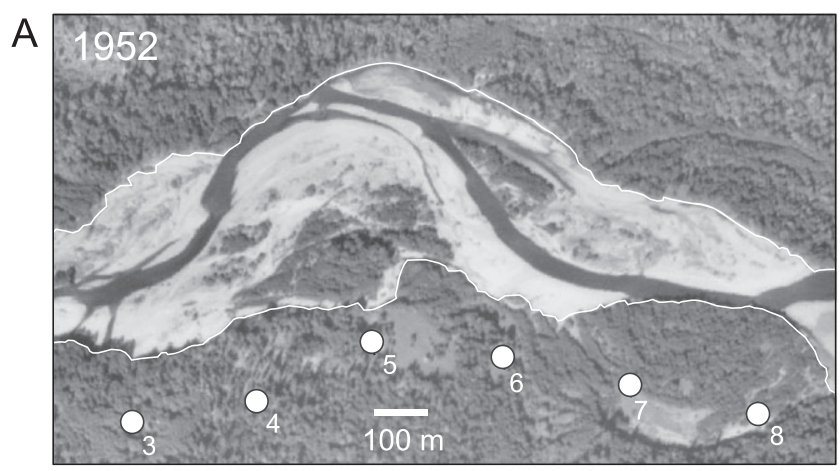

B

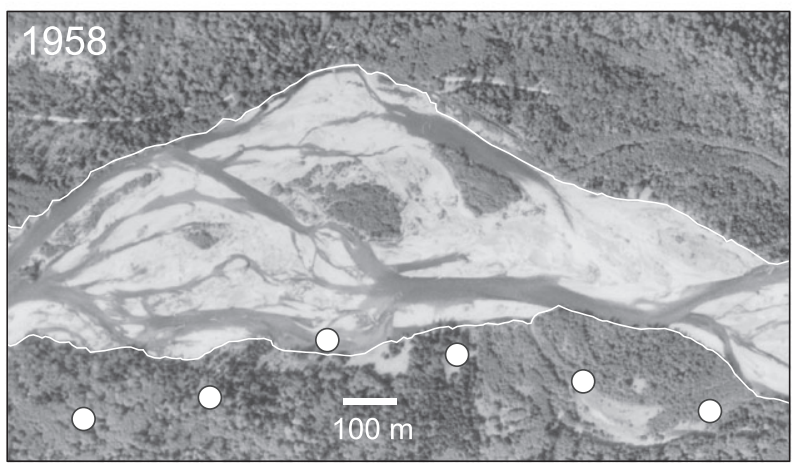

Figure 5. Photographs from the Quinault River study reach showing an example of disturbance, with active channel widening and becoming more braided between (A) 1952 and (B) 1958, an interval that encompassed the second-highest flood peak on record for that river (an event slightly below the Q50 value). White circles show points corresponding to transects 3-8 (Figure $2(\mathrm{C})$ ); circles indicate approximate center of active river corridor as of 2013. White lines show the margins of the inferred recently active flow zone.

\section{A}

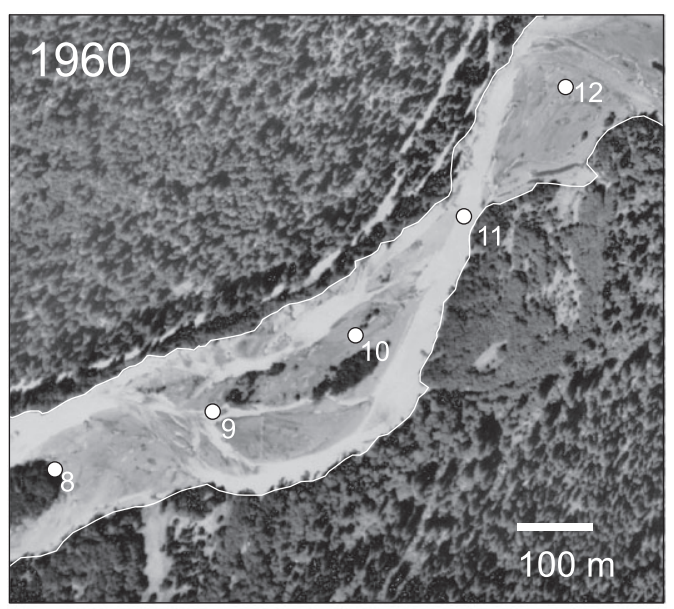

B

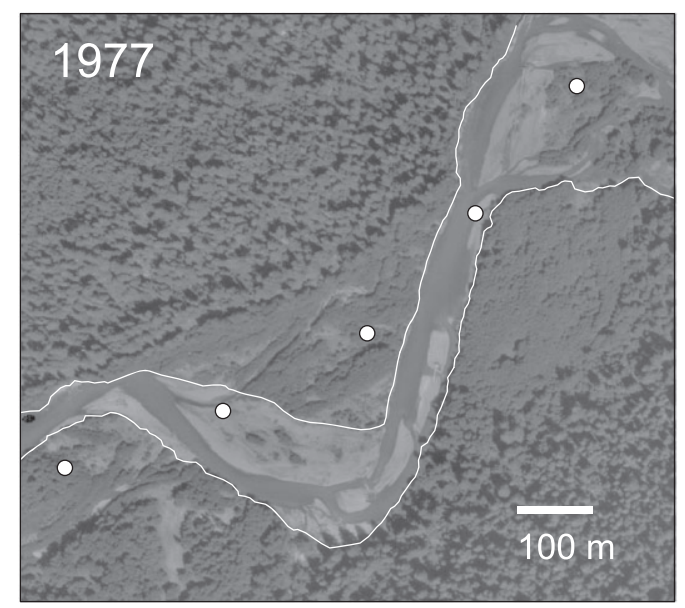

Figure 6. Photographs of the Hoh River study reach showing narrowing and simplification (decreased braiding) between (A) 1960 and (B) 1977. White circles show points corresponding to transects 8-12 (Figure 2(A)); circles indicate approximate center of active river corridor as of 2013.

active flow zone varied by a factor of 6-9 within each reach. Channel planform varied from (rarely) single-thread to commonly having four or more wetted braids, and sometimes many more (e.g. portions of the Quinault reach in 1958 with 10 braids; Figure 5). Nearly every part of each reach showed some change over time due to meander migration of individual channel threads and avulsion of new channels, as is common in braided and island-braided rivers.

The aerial photographic record contained many examples of apparent disturbance, such as widening and braiding over subdecadal time scales. We also observed examples of river corridors becoming narrower and less braided; this was most pronounced during the 1970s (Figures 6 and 7). We did not find evidence for hydrologic disconnection between channel and floodplain in any reach (long-term abandonment of large swatches of floodplain), nor did we see evidence of recent incision, such as new development of inset terraces (the edges of which should have been resolvable in images starting around 2000 if the scarps were at least $\sim 1 \mathrm{~m}$ wide), although relict, vegetated geomorphic surfaces are apparent at various elevations due to fluvial and glacial history (Swanson and Lienkaemper, 1982; Bountry et al., 2005). Over much of each reach, the active river corridor shifted back and forth laterally by hundreds of meters during the 74 years evaluated.

All four rivers have widened significantly over the past several decades after having been relatively narrow in the 1970s; the Hoh, Queets, and Quinault had narrowed during the 1960s and early 1970s (Figure 7). The Hoh River reach showed 

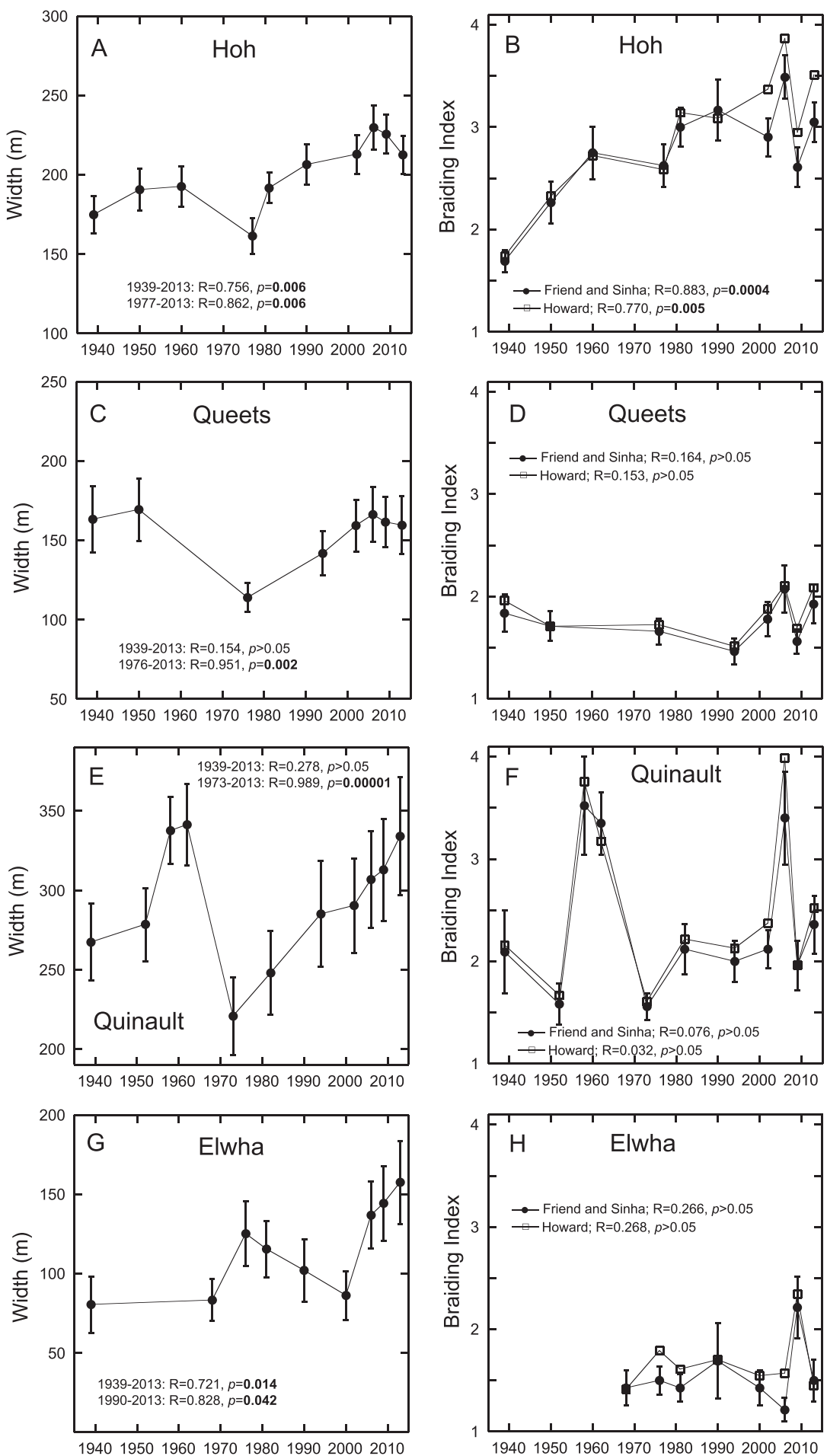

Figure 7. Mean width of the recently active flow zone, and braiding indices of Friend and Sinha (1993) and Howard et al. (1970), for study reaches on the Hoh River (A, B), Queets River (C, D), Quinault River (E, F), and Elwha River (G, H). The legend for braiding indices in (B) also applies to (D), (F), and $(\mathrm{H})$. Error bars indicate standard error of the mean. $\mathrm{R}$ and $P$ values on each plot were determined by Student's $t$ tests on linear regressions for the temporal spans indicated.

a significant increase in channel braiding over the aerial photographic record, whereas the other rivers showed no temporal trend in the degree of braiding (Figure 7). Details of channel change, and association with potential drivers, are discussed for each river individually below.

\section{Hydrology}

Our analysis of temporal changes in flood magnitude showed that Q2 (two-year-flood) values were relatively low in the late 1960s and early 1970s, but increased thereafter (Figures 4, A6), consistent with previous findings of greater flood magnitude and frequency in recent decades in this region (Piety et al., 2004; Bountry et al., 2005; Beschta and Ripple, 2008; Czuba et al., 2012; Tohver et al., 2014). The Q2 magnitudes over the most recent $\sim 4$ decades have been $10-35 \%$ greater than over the entire length of each stream-gage record. The Q2 value calculated for the Hoh River for 1978-2013 (i.e. since the recent Q2 rise apparently began, through the end of the aerial photographic record) was $1024 \mathrm{~m}^{3} / \mathrm{s}$, whereas the Q2 value for the entire 
period of record at station 12041200 (Figure 1) is $924 \mathrm{~m}^{3} / \mathrm{s}$. The three highest flood peaks recorded on the Hoh River have occurred since 2002 - three events exceeding the calculated Q10 (10-year-flood peak; Figure 4(A)). On the Queets River, the Q2 value for 1978-2013 was $2131 \mathrm{~m}^{3} / \mathrm{s}$, whereas the Q2 for the period of record is $1902 \mathrm{~m}^{3} / \mathrm{s}$. On the Quinault River the Q2 value for 1978-2013 was $808 \mathrm{~m}^{3} / \mathrm{s}$, whereas the Q2 value for the entire Quinault River record is substantially lower at $595 \mathrm{~m}^{3} / \mathrm{s}$. The Q2 value for 1978-2013 on the Elwha River was $477 \mathrm{~m}^{3} / \mathrm{s}$, whereas the Q2 value for the entire period of record is $421 \mathrm{~m}^{3} / \mathrm{s}$.

Stage-discharge histories of the four rivers did not yield clear evidence for system-wide, major bed aggradation in the first few decades of the twentieth century (Figure A7). The Hoh River record indicated no substantial bed-elevation changes between 1926 (when station 12041000 was established; Figure 1) and 1950. Stage at a discharge of $226 \mathrm{~m}^{3} / \mathrm{s}$ fluctuated negligibly, within a range of $0.14 \mathrm{~m}$, over those decades. The stage-discharge history at the Queets gaging station (12040500) indicated minor bed aggradation in 1935 (a stage increase of $0.33 \mathrm{~m}$ at $991 \mathrm{~m}^{3} / \mathrm{s}$ ) that immediately followed a Q50 flood event; stage decreased by $\sim 0.2 \mathrm{~m}$ over the subsequent decade (Figure A7). The Quinault River record (station 12039500) showed negligible change between 1911 and 1950 . Stage at $283 \mathrm{~m}^{3} / \mathrm{s}$ varied by no more than $0.1 \mathrm{~m}$ over those decades, indicating essentially no bedelevation change in the region of the river corridor where the gage is situated, below Lake Quinault. The Elwha River record (station 12045500) record indicated minor scour and fill in the early $20^{\text {th }}$ century. Stage there fluctuated within a 0.32-m range between 1918 and 1927, commonly changing by $\sim 0.1 \mathrm{~m}$ over monthly to annual intervals, with no directional trend (Figure A7). After 1927 a 64-m-high dam, Glines Canyon Dam, was present upstream from the Elwha gage site (Figure 1), trapping sediment in a reservoir such that the gage location would have been much less sensitive to upstream sediment-supply changes. For comparison, removal of that dam and associated reservoir-sediment erosion caused a $1.3-\mathrm{m}$ stage increase at this same gage site in 2012-2013 (East et al., 2015a).

\section{Elk-population changes}

Our reanalysis of ONP elk-population changes over the past century indicated a peak in the late 1910s-1930s, followed by a gradual decline in abundance (Figure 8(A); Lovejoy, 1911; Fromme, 1915; Bailey, 1918; A. Murie, 1935a; National Park Service, 1937; Schwartz, 1939; Newman, 1954; Houston et al., 1990; Jenkins and Manly, 2008). The pattern shown in Figure 8(A) generally agrees with that presented by Beschta and Ripple (2008). Between 1937 and 2002 the primary year-round ONP elk population apparently declined at an annual rate of $0.5 \%$ (i.e. $r=-0.005$ ), a net decline of $\sim 25 \%$ over those 65 years (Figure $8(\mathrm{~A})$ ). Although some estimates indicated population decline during the late 1930s (Schwartz, 1939) and relative stability between the 1950s and 1990 (Houston et al., 1990), the dearth of reliable estimates does not allow us to determine with certainty whether the decline between 1937 and 2002 was constant or punctuated. Between 1985 and 2010 the elk subpopulations in the Hoh and Queets valleys declined at annual rates of $0.8 \%$ and $1 \%$, respectively (Figure 8(B), (C)). Collectively, the available data indicate that elk abundance declined during the period coinciding with the aerial photographic record.
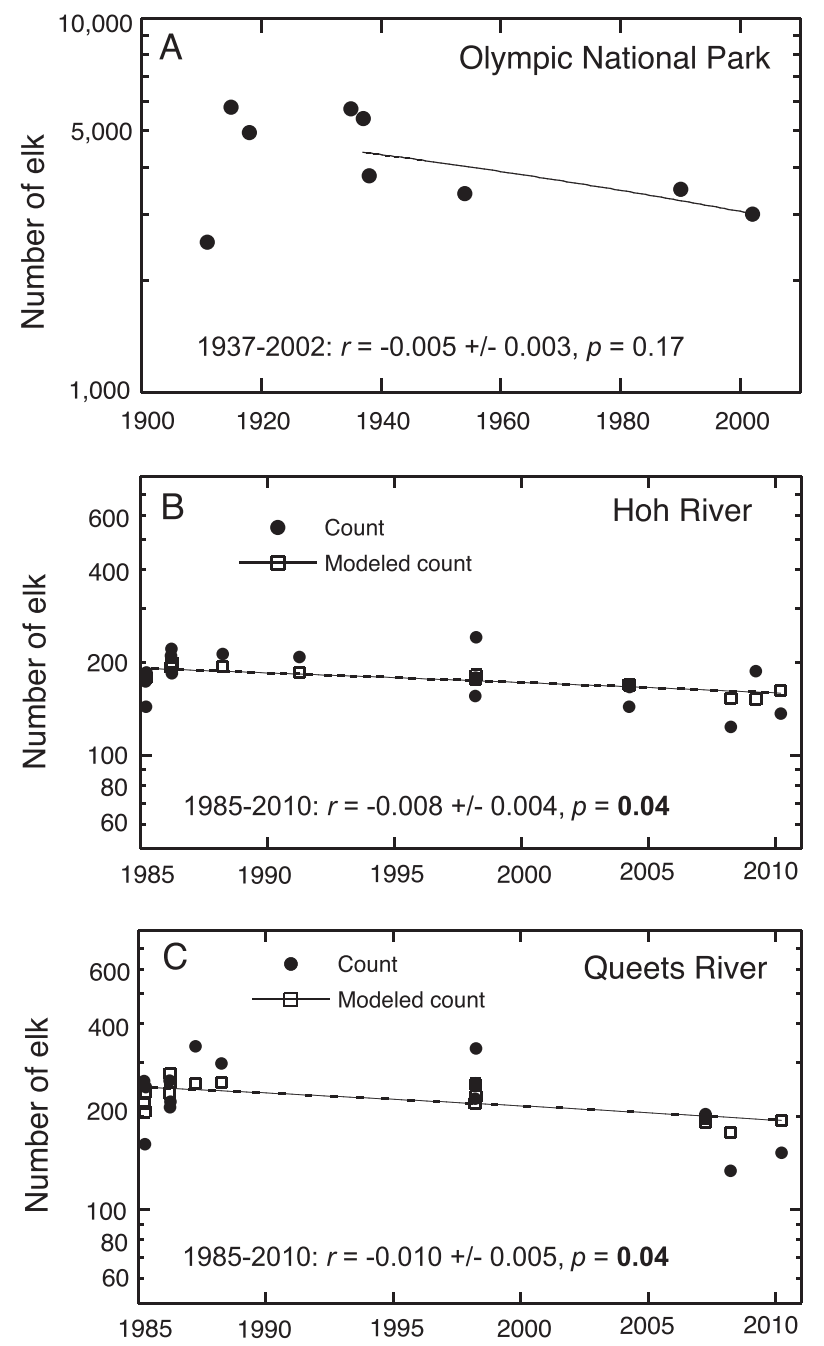

Figure 8. Estimates of elk abundance in primary elk ranges within Olympic National Park (ONP). (A) Compilation of historical estimates of elk populations occupying the primary year-round elk range within ONP: Elwha, Sol Duc, Calawah, Bogachiel, Hoh, Queets, and Quinault Valleys combined, 1911-2002. Data sources: Lovejoy (1911), Fromme (1915), Bailey (1918), A. Murie (1935a), National Park Service (1937), Schwartz (1939), Newman (1954), Houston et al. (1990); we used the midpoint of population-range estimates provided by their study), and Jenkins and Manly (2008). (B) Number of elk counted by aerial survey in the Hoh River corridor within ONP. (C) Number of elk counted by aerial survey in the Queets River corridor within ONP. (B) and (C) show raw counts and also predicted counts derived from the model of Jenkins et al. (2015) that adjusts for year day, growing degree days preceding the survey, and minimum temperature on the morning of the survey. Exponential rate of population change, $r$ (sensu Caughley and Birch, $1971) \pm$ standard error (SE) and significance level, is shown for specified time intervals.

\section{Relationship of channel planform to hydrology and elk abundance}

Peak flood discharge (FLOOD), with and without the added effect of ELK, was the strongest predictor of both channel width and braiding among the four study reaches combined (Table I). A positive association of FLOOD with channel width and braiding was strongly supported, with $99 \%$ and $88 \%$ of the cumulative model weight, respectively. A counterintuitive, negative association of width and braiding with ELK also was supported in combination with MAF $(67 \%$ and $32 \%$ of cumulative model weights for channel width and braiding, respectively). There was essentially no support for any other models relating channel width to MAF, ELK, or the NULL (constant) model, and considerably less support for the associations 
Table I. Relative strength of associations between channel characteristics (width and braiding indices) and factors potentially affecting planform (FLOOD, MAF, and ELK; see text for explanation of model parameters)

\begin{tabular}{|c|c|c|c|c|c|c|c|c|}
\hline Model & Independent variable & Slope & SE(Slope) & $p$ (Slope) & $\mathrm{n}$ & $K^{a}$ & $\Delta \mathrm{AIC}_{C}^{\mathrm{b}}$ & $w_{i}^{\mathrm{c}}$ \\
\hline \multicolumn{9}{|l|}{ Channel Width } \\
\hline \multirow[t]{2}{*}{ FLOOD + ELK } & FLOOD & 0.251 & 0.060 & $<0.01$ & 38 & 4 & 0.00 & 0.669 \\
\hline & ELK & -2.367 & 1.213 & 0.06 & & & & \\
\hline FLOOD & FLOOD & 0.289 & 0.059 & $<0.01$ & 38 & 3 & 1.42 & 0.329 \\
\hline ELK & ELK & -4.109 & 1.388 & $<0.01$ & 38 & 3 & 13.04 & 0.001 \\
\hline \multirow[t]{2}{*}{$M A F+E L K$} & MAF & -0.152 & 0.397 & 0.7 & 38 & 2 & 13.42 & 0.001 \\
\hline & ELK & -4.011 & 1.4009 & $<0.01$ & & & & \\
\hline NULL (constant) & NA & NA & NA & NA & 37 & 3 & 19.02 & 0.000 \\
\hline MAF & MAF & 0.101 & 0.425 & 0.81 & 37 & 4 & 20.32 & 0.000 \\
\hline \multicolumn{9}{|l|}{ Channel Braiding } \\
\hline FLOOD & FLOOD & 0.288 & 0.098 & $<0.01$ & 37 & 3 & 0.00 & 0.554 \\
\hline \multirow[t]{2}{*}{ FLOOD + ELK } & FLOOD & 0.247 & 0.103 & 0.02 & 37 & 4 & 1.07 & 0.324 \\
\hline & ELK & -2.568 & 2.200 & 0.25 & & & & \\
\hline ELK & ELK & -4.365 & 2.202 & 0.06 & 37 & 3 & 4.28 & 0.065 \\
\hline \multirow[t]{2}{*}{$\mathrm{MAF}+\mathrm{ELK}$} & MAF & 0.574 & 0.621 & 0.36 & 36 & 4 & 7.22 & 0.015 \\
\hline & ELK & -3.878 & 2.298 & 0.1 & & & & \\
\hline MAF & MAF & 0.803 & 0.622 & 0.21 & 36 & 3 & 7.66 & 0.012 \\
\hline
\end{tabular}

${ }^{\mathrm{a}}$ Number of parameters estimated in model.

${ }^{\mathrm{b}}$ Difference between the model $\mathrm{AIC}_{C}$ and the lowest $\mathrm{AIC}_{C}$.

${ }^{\mathrm{c}}$ Akaike weight (relative weight of evidence in favor of the ith model).

between braiding and MAF, ELK, or the NULL model. Because the interpolated estimate of elk abundance is perfectly negatively correlated with time $(r=-1.0)$, our $\mathrm{AIC}_{c}$ analysis shows the effect of declining elk abundance confounded with the positive effect of time (Figure 8(A), Table I), as well as potentially other unmeasured temporal effects.

Strong support for the influence of recent flood magnitude (FLOOD) on channel planform warrants a more focused look at individual watersheds. We identified significant positive correlations between width and recent flood magnitude for the data set as a whole, and also for each watershed individually (Figure 9(A)). The degree of braiding correlates positively with flood history for the entire data set and also for the Hoh and Quinault watersheds individually, the two from which we have the most channel-planform data (Figure 9(B)). We found no correlation between width and the recent mean annual flow history, nor between braiding and mean annual flow, for any watershed nor for the data set as a whole (Figure 9(C), (D)). Channel width and interpolated park-wide elk population are negatively correlated on the Hoh and Elwha Rivers (no correlation on the Queets or Quinault), as are channel braiding and interpolated elk population on the Hoh (Figure $9 €,(F)$ ). Thus, the data support our first hypothesis - that greater recent flood magnitude corresponds to wider, more braided channels - but do not support our alternative hypothesis that greater elk abundance would correspond to greater width and braiding.

\section{Hoh River}

Notable features of the Hoh River record include a decrease in channel width and braiding in 1977 relative to 1960 (Figures 6, 7(A)), which interrupted the significant multi-decadal trends toward increased width and braiding of this reach. That interval corresponded to low peak-flow conditions; culminating a relatively quiescent flood regime of the late 1960s and early 1970s, the peak flow in winter 1976-1977 was exceptionally low, being only $36 \%$ of the Q2 value, the lowest annual peak in the Hoh discharge record (Figure 4(A)). Thus, although that year was otherwise hydrologically normal, with spring snowmelt flows $85 \%$ of average, the lack of channel disturbance by winter flood events was unusual; the river corridor narrowed by
17\% between 1960 and 1977 and became colonized by new vegetation. Width and braiding increased significantly over subsequent decades with higher peak flows (Figures 7(A), (B), A6). We measured the greatest width and braiding on the 2006 images (Figure 7(A), (B)), which followed the flood of record by less than three years (a > Q25 event in October 2003).

Notes from a GLO cadastral survey of the Hoh River in 1919 include width measured at one location within our study reach where the survey crossed orthogonal to the river corridor (BLM, 2016). That measured width of $77 \mathrm{~m}$ was narrower than measured at the same location on the 2013 aerial photographs $(133 \mathrm{~m})$, although the 1919 measurement was within the range of spatial and temporal variability for this reach that we measured in the aerial photographic record (Figure A5).

\section{Queets River}

The greatest-magnitude planform changes along the Queets River reach involved substantial narrowing between 1950 and 1976 (mean width decreased from $169 \mathrm{~m}$ to $114 \mathrm{~m}$, or $33 \%$; Figure $7(C)$ ). Because peak-flow data are missing from 19681974, we cannot establish clear temporal correspondence between flow and channel-planform changes. However, if the Queets River hydrology behaved similarly to that of the other rivers in having had a relatively quiescent flood regime in the late 1960s and early 1970s, that would be consistent with narrowing of the active flow zone over that time step. We measured increased width and braiding, and major channel reorganization, over the 1994-2002 photographic interval (Figure 7 (C), (D)), a time step that included the flood of record, a peak slightly above the Q50 value in December 1999 (Figure 4(B)). Additional braiding fluctuations occurred in the late 2000s, though width was essentially constant after 2002.

A 1906 GLO survey of the Queets River measured channel width at three transects orthogonal to the river corridor within our study reach (BLM, 2016). Those measurements of 74-138 $\mathrm{m}$ are similar to or slightly narrower than at the same locations in 2013 (74-172 m), and are within the spatial and temporal range for this reach that we measured throughout the aerial photographic record (Figure A5). 

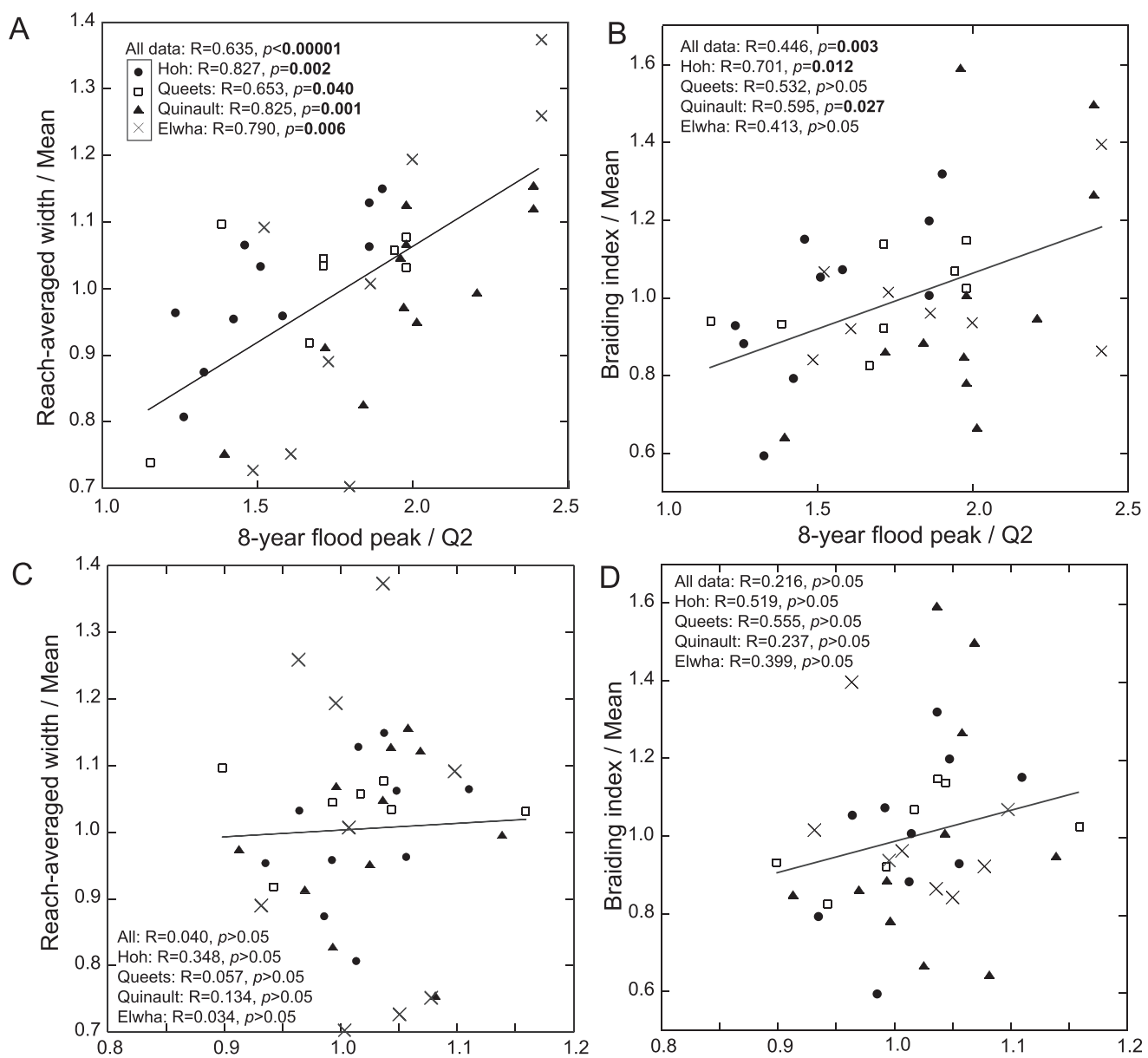

8 -year mean annual flow / Whole-record mean
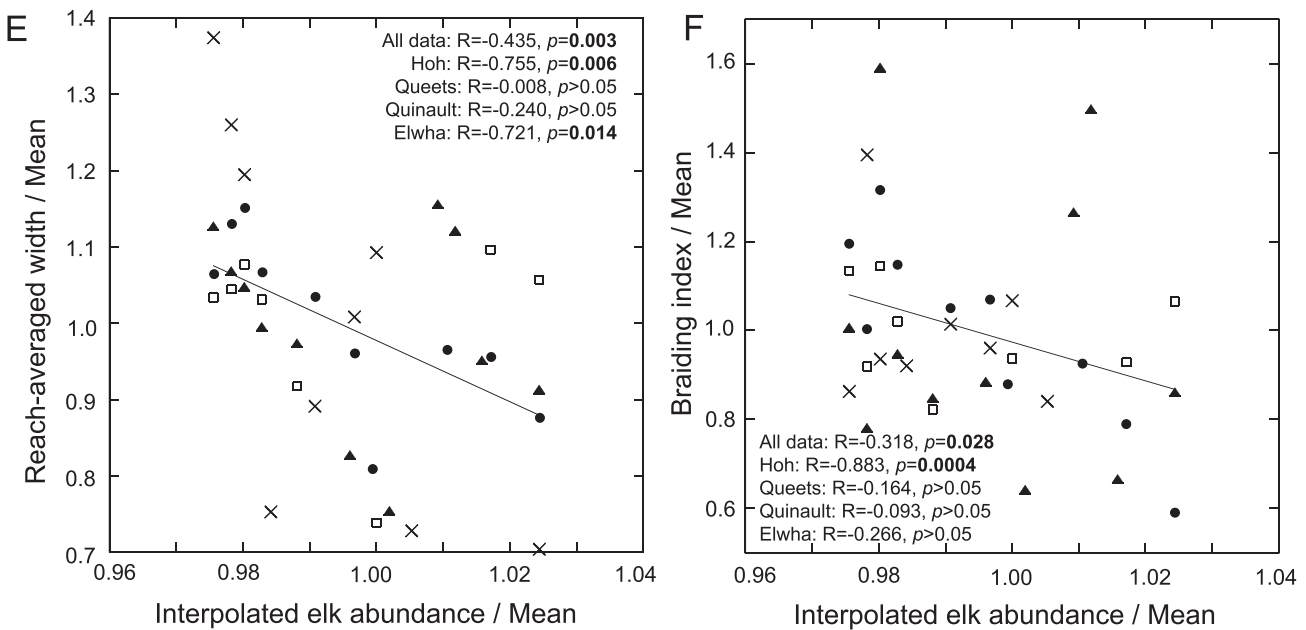

Figure 9. Relationships of recent flood magnitude, recent mean annual flow history, and elk abundance to channel width and braiding. Tables within each plot show results of Student's $t$ tests on linear regressions; $P$ values $<0.05$ in bold. (A) Relationship between recent flood magnitude and width. Horizontal axis shows the largest flood peak on each of the four rivers in the 8 years preceding each set of aerial images, normalized by the respective 2-year flood peak magnitude (Q2) for each river. Vertical axis indicates reach-averaged width (data from Figure 7) normalized by the mean reachaveraged width for each river, respectively. Each data point represents one set of aerial images. (B) Relationship between recent flood magnitude and channel braiding. Horizontal axis as in (A); vertical axis shows Friend and Sinha braiding index calculated from each set of aerial photographs normalized by the mean value obtained from all image sets for each river, respectively. (C) Relationship between recent mean annual flow (averaged over the 8 years preceding each set of aerial images, then normalized by mean annual flow over the entire period of record for each river) and width (normalized as in A). (D) Relationship between normalized recent mean annual flow and normalized channel braiding. (E) Relationship between interpolated elk abundance, normalized by the mean value obtained from linear regression of the natural logarithm of elk population against time (1937-2002 data in Figure 8(A)), and normalized channel width. (F) Relationship between normalized interpolated elk abundance and normalized channel braiding.

\section{Quinault River}

The largest changes on the Quinault reach involved a substantial, short-lived width and braiding increase between 1952 and 1958 (Figures 5, 7(E), (F)) - width increased by $18 \%$ then. That 6-year interval included a November 1955 flood that was the second-highest peak in the Quinault discharge record, an event slightly below the Q50 value (Figure $4(\mathrm{C})$ ). Width and braiding decreased after 1962, with mean width dropping by $35 \%$ between 1962 and 1973 to the lowest value for this river in the 
photographic record, due to abandonment of several anabranches along the north (river-right) side of the upper $3 \mathrm{~km}$ of the reach (Figure A3). Channel narrowing and simplification accompanied relatively quiescent peak flows - no flows approached the Q10 value between 1962 and 1973, in contrast to larger floods in the preceding and succeeding photographic intervals (Figure $4(C)$ ).

The Quinault channel became significantly wider after 1973, accompanied by generally larger floods (Figure A6). We measured a large braiding increase between 2002 and 2006 accompanied by a modest width increase (Figure 7(E), (F)); this interval included a $>$ Q10 flood in October 2003. That spike in channel braiding was short-lived, and by summer 2009 the degree of braiding had returned to its lower 1990s-2002 values.

The Quinault reach is wider than the Hoh and Queets reaches (which have comparable gradient), despite the Quinault River discharge being less than that of the Hoh or Queets Rivers. Median reach-averaged width of the Quinault over the photographic record $(299 \mathrm{~m})$ was $\sim 30 \%$ greater than that of the Queets $(227 \mathrm{~m})$ and $50 \%$ greater than on the Hoh $(200 \mathrm{~m}) ; P<0.0001$ in Welch's t-tests for each comparison. We did not detect significant differences in braiding between the Quinault reach and those on the Hoh or Queets Rivers.

A 1908 GLO Quinault River survey included four width measurements within our reach that were orthogonal to the river corridor (BLM, 2016), ranging from 163 to $354 \mathrm{~m}$. These generally agreed with widths at those locations on the 2013 aerial photographs (231-334 m), and were within the range of spatial and temporal variability that we measured in the Quinault reach throughout the aerial photographic record (Figure A5).

\section{Elwha River}

Planform change on the Elwha River corresponded temporally with known landslide activity, as well as with floods. Although sediment-load data are not available that could be compared with channel planform over long time scales, a landslide event provided an opportunity to assess response to a sedimentsupply increase in this setting. All four watersheds have active landslides (Quinault Indian Nation, 1999; Lyon, 2003; Godaire and Kimbrel, 2015), but the Elwha is the only one of our study reaches where landslide debris entered the mainstem channel immediately upstream from the reach $(350 \mathrm{~m}$ upstream, in a bedrock canyon; another landslide occurs $2.8 \mathrm{~km}$ upstream of the reach). The Elwha River is also the only one of our study rivers with a documented major landslide recently; in this remote area, landslides usually go unobserved. The landslide $350 \mathrm{~m}$ upstream from the reach dammed the river temporarily in 1967, and the debris-dam failure released a flood wave several meters high (Tabor, 1987; Acker et al., 2008). Reworked material from the failed landslide dam had formed a 25-ha debris fan in the upper part of our study reach by 1968 . This substantially widened the upstream-most part of the reach between 1939 and 1968 (locally by as much as $123 \mathrm{~m}$, or $540 \%$ ), although the landslide sediment pulse had not progressed far enough downstream by 1968 to increase mean width over the entire reach (Figures. $7(\mathrm{G}), \mathrm{A} 4$ ). Over subsequent decades the river reworked the debris fan into several surfaces of different elevation; the fan directed the river more toward the right bank, further increasing the sediment and wood load added to the river (Acker et al., 2008). The reach-scale increase in mean width as of 1976 relative to 1968 is attributable to downstream progression of that sediment pulse. The upper half of the reach accounted for most of the increased width and braiding over those 12 years (Figure A4). Any tendency for the Elwha channel to have narrowed or become less braided during relatively quiescent flood activity of the early 1970s (Figure 4(D)), as occurred then on the Hoh, Queets, and Quinault Rivers, was apparently obscured by the landslide sediment pulse dispersing through the reach.

The second major Elwha River planform change occurred after 2000, when reach-averaged width nearly doubled (from $86 \mathrm{~m}$ to $157 \mathrm{~m}$ between 2000 and 2013; Figure 7(G)), affecting all parts of the reach (Figure A4). Within that transition to a wider reach, we measured a distinct short-lived braiding increase between 2006 and 2009 that coincided with a 50-year flood in December 2007 (Figures 4(D), 7(H)). Field topographic surveys in the lowermost part of this reach constrained the timing of new braid formation to between September 2007 and April 2008, months with no other notable floods (Draut et al., 2011). In the 2-3 years following that Q50 flood, the Elwha reach gradually returned to having one to two active threads (Figure 7(H); Draut et al., 2011; East et al., 2015a). In general the widening of the Elwha reach in recent decades is consistent with greater flood activity compared to earlier in the record (Figure A6).

A 1911 GLO survey recorded width orthogonal to the river corridor at one location within our Elwha River reach, measuring $64 \mathrm{~m}$ where we measured a width of $72 \mathrm{~m}$ on the 2013 aerial photographs. The $64-\mathrm{m}$ width is within the range of spatial and temporal variability throughout the aerial photographic record (Figure A5).

\section{Discussion}

Rivers of the Olympic Peninsula are dynamic systems exhibiting substantial spatial and temporal variation, including repeated geomorphic disturbance and recovery over subdecadal time scales. The magnitudes and styles of channel change that we observed in the aerial photographic record of the Hoh, Queets, Quinault, and Elwha Rivers are consistent with previous studies of coastal Pacific Northwest rivers in showing major spatial and temporal heterogeneity of floodplains and their forests (Fetherston et al., 1995; Abbe and Montgomery, 2003; O'Connor et al., 2003; Piety et al., 2004; Bountry et al., 2005; Beechie et al., 2006; Latterell et al., 2006; Van Pelt et al., 2006).

Our data indicate that flood activity has been an important driver of channel planform in ONP rivers over the threequarters of a century covered by aerial photographic records. We also find circumstantial evidence that sediment supply influences channel width and braiding in this setting, as does a possible legacy effect of human alteration on the Quinault River. Elk abundance does not correspond temporally to wider or more braided channels, nor do elk population and channel morphology trend in the same direction over decadal time scales, suggesting that any signal of elk influence on channel dynamics is overwhelmed by geomorphic response to physical drivers.

\section{Physical drivers of channel change}

Channel planform on the Hoh, Queets, Quinault, and Elwha Rivers evidently responds to hydrologic forcing - floods, and at times a relative lack of flood activity, as in the late 1960s and early-middle 1970s. Intervals spanning large floods generally were accompanied by widening of the active flow zone and increased channel braiding, whereas intervals with lower peak flows corresponded to active-flow-zone narrowing and 
reduced braiding (Figures 7, 9, A6). However, these braided and island-braided rivers have enough inherent stochasticity not to respond in a quantifiably predictable fashion to every hydrologic fluctuation. The scatter in data relating width or braiding to flood history (Figure 9(A), (B)) is expected in forested gravel-bed river systems, given the great variety of possible antecedent conditions, flow sequencing, and large-wood movement. Thus, although flow history cannot be inferred in detail from every fluctuation in width or braiding, on these rivers the major highs and lows in the hydrologic record corresponded with the expected style of planform change. The significant widening of all four rivers since the 1970s is attributable to the known intensification of regional flood activity since that time, which began with a transition to a wetter PDO phase in the fall of 1977 (Mantua et al., 1997; Piety et al., 2004; Bountry et al., 2005; Beschta and Ripple, 2008; Czuba et al., 2012). Our finding that the recent mean annual flow history does not correlate with river width or braiding (Figure 9(C), (D)) is consistent with previous work showing that the largestmagnitude geomorphic changes in this setting occur during winter storm-driven floods rather than during the lowermagnitude spring-snowmelt high flows (Draut et al., 2011).

Interpretations of channel response to floods and other abrupt disturbances depend strongly on how closely in time measurements (photographs) follow the disturbance event (cf. Draut et al., 2011). Because river morphology in this setting can recover rapidly from individual floods, especially from a flood-induced braiding increase (Figures $7(\mathrm{~F}),(\mathrm{H})$ ), inferred planform state or rates of channel change vary markedly depending on whether geospatial measurements follow 1-2 years or 5-7 years after a flood. Rates and styles of channel recovery also can vary substantially depending on what part of the river corridor was disturbed. When the active flow zone widens by eroding into high-elevation Late Pleistocene or Holocene terraces, as several recent floods have done on the Quinault and Elwha Rivers (Bountry et al., 2005; Draut et al., 2011), the new, lower-elevation floodplain area is likely to be reoccupied and disturbed again by future floods (cf. Konrad, 2012) and the river corridor may not return to a state as narrow as before the ancient terrace was disturbed (Beschta and Ripple, 2008). A recovery to pre-flood width is more likely when flood-induced channel migration or avulsion affects lower-relief floodplain areas.

River planform typically is also sensitive to sediment supply, with increased supply commonly promoting bed aggradation that leads to greater channel width and braiding (Smith and Smith, 1984; Schumm, 1985; Simon, 1999; Miller and Benda, 2000; Ashworth et al., 2004; Hoffman and Gabet, 2007; Gran, 2012; Podolak and Wilcock, 2013). We have shown that increased width and braiding through the Elwha River study reach in the late 1960s and 1970s accompanied dispersion of a landslide-induced sediment pulse (cf. Acker et al., 2008). A similar, though larger, response occurred on a downstream section of the Elwha River beginning in 2012 during a sediment pulse from intentional dam removals, wherein the Friend and Sinha braiding index temporarily increased from $\sim 2$ to 3 (East et al., 2015a).

We surmise that the strong temporal trend toward greater braiding of the Hoh River may result from increased sediment supply due to glacial retreat in the upper watershed. Glaciers in the Olympic Mountains have retreated rapidly over recent decades, concurrent with regional warming (Rasmussen and Conway, 2001; Malcomb and Wiles, 2013) - since 1980, ONP has lost $34 \%$ of its glacial ice area and 82 glaciers have disappeared entirely (Riedel et al., 2015), newly exposing unconsolidated, unvegetated sediment high in the watersheds. The Hoh watershed contains by far the greatest proportion of
Olympic Mountains glacial ice volume $(65 \%)$, and the basins with the next-most have much less: the Elwha has $11 \%$, the Queets has 9\%, and the Quinault and several other basins each have $<5 \%$ (Riedel et al., 2015). Thus, the Hoh River would be particularly sensitive to increased sediment supply exposed by retreating glaciers (and also shrinking perennial snow fields). Moreover, the Hoh River has no lakes to intercept glacial sediment yield. Changes in sediment supply cannot be explained by any enhancement of landslide activity between the 1930s and 2000s (Lyon, 2003). Lacking sediment-flux measurements from the Hoh River, we cannot confirm our proposed explanation for increased braiding, and the range of possible fluvialplanform response to glacier recession is generally not well understood. Fluvial geomorphic and sediment-export adjustment to glacial retreat vary according to local topographic controls, hillslope-channel connectivity, and the relative effects of glacial melting on sediment supply and transport capacity (Marren and Toomath, 2014; Micheletti and Lane, 2016; Lane et al., in press). However, several previous studies support our interpretation that enhanced bar and braid formation may reflect sediment-supply increase driven by glacial recession. Increased sediment load during rapid glacier recession has been documented from lake cores in British Columbia (Leonard, 1997; Menounos and Clague, 2008; Schiefer et al., 2010), and warmer temperatures can correspond to enhanced sediment export from some alpine basins with retreating glaciers (Lane et al., in press); bar development in gravel-bed channels is also known to vary with bedload flux $\left(\mathrm{O}^{\prime}\right.$ Connor et al., 2014). One study has shown increased river width and braiding downstream from retreating glaciers in British Columbia (Miles and Allegretto, 2011). Czuba et al. (2012), investigating rivers that drain retreating glaciers on Mt. Rainier, Washington, found that channel width correlated with the proportion of sedimentary debris mantling the glacier; their study did not measure braiding. Based on these related studies, as well as the field and flume work cited above showing that braiding commonly increases with sediment supply, we suggest that the strong trend toward increased braiding on the Hoh River, as well as some of its recent widening, may reflect sensitivity to increased bedload resulting from glacial retreat.

Fluvial geomorphic patterns in this setting thus likely reflect climatic variations -changes in flood regime as well as sediment-supply changes caused by landslides and, we suspect, glacial recession, and therefore appear to be an example of alpine-watershed sensitivity to climate-driven changes (cf. Micheletti et al., 2015; Praskievicz, 2015; Micheletti and Lane, 2016). These rivers also demonstrate transmission of climatic signals through a relatively short sediment-routing system that lacks substantial buffering by sediment storage (i.e. $\sim 50 \mathrm{~km}$ from glaciated regions to our Hoh River reach), which can limit signal propagation in other environments or over larger spatial or temporal scales (Van Den Berg Van Saparoea and Postma, 2008; Simpson and Castelltort, 2012; Armitage et al., 2013; Blöthe and Korup, 2013; East et al., 2015b). Sediment-routing systems with similar geomorphic processes and scale (10s$100 \mathrm{~s} \mathrm{~km}$ long) would transmit signals less effectively if they have less inherent connectivity than our reaches do, e.g. if lakes intercept sediment transport (as Lake Quinault does downstream of our study reach; Figure 1).

A legacy of anthropogenic physical alterations may affect the Quinault River (cf. Bountry et al., 2005; Herrera Environmental Consultants, 2005). The wide active flow zone there compared to the Hoh and Queets Rivers may result from logjam and tree removal and anthropogenic riverbank disturbances decades ago contributing to an unnaturally dynamic channel. The other three study reaches were affected by such activities much less or not at all (Bountry et al., 2005; Latterell and Naiman, 
2007). However, comparisons of 2013 channel widths with those measured in the 1908 GLO survey of the Quinault reach do not indicate a significant width increase between those dates. A cursory GIS analysis of the 2013 aerial images shows that the Quinault reach still has less woody debris than the other three rivers $-1.9 \%$ woody-debris cover, by area, compared with $2.7 \%$ on the Hoh, $2.5 \%$ on the Queets, and $5.4 \%$ on the Elwha reach (the Elwha, being smaller and steeper, is expected to have proportionally more woody debris cover than the other rivers).

\section{Influence of top-down trophic cascades}

Our findings suggest that the effects of elk on river-planform evolution are subsidiary to effects of physical forcing, contrary to the hypothesis that intensive elk use (a result of wolf extirpation) has been the primary factor driving river-planform evolution. If today these rivers were driven substantially by a legacy effect wherein they are still recovering from elk overuse 8090 years ago, when browsing and bank trampling would have been most intensive, we would expect decreasing width and braiding over the 74-year photographic record. We have not found such a relationship between elk abundance and channel evolution in our data. Despite considerable uncertainty in the early elk-population estimates, recent surveys substantiated a decline over at least the past 25 years in two of our four study watersheds (Figure $8(B),(C))$, while the channels widened significantly (Figure 7). We interpret the negative correlation between interpolated elk abundance and channel width and braiding as most likely spurious, representing correlation without causation. We considered the possibility of some reverse causal mechanism - whether large floods may contribute to elk decline by eliminating habitat or reducing habitat quality - but find this unlikely, as early seral vegetation on immature floodplains is an important elk-habitat component in ONP and elsewhere in the coastal Pacific Northwest (Raedeke and Tabor, 1982; Jenkins and Starkey, 1984), and the proportion of transitional plant communities has remained fairly constant throughout the aerial photographic record (Latterell et al., 2006).

Though our conclusions are drawn largely from temporal analyses, we can also consider whether spatial differences in elk use among the four study reaches may affect channel dynamics. Ground-based fecal-pellet surveys have shown that elk density (elk use per unit area) is broadly similar among the four river corridors we examined for planform change, although slightly higher in the Queets. Elk densities in 20012002 were $5.1 \pm 1.7$ ( $1 \mathrm{SE}$ ) elk/ $/ \mathrm{km}^{2}$ in the Hoh, $7.7 \pm 2.1$ $\mathrm{elk} / \mathrm{km}^{2}$ in the Queets, $6.2 \pm 1.4 \mathrm{elk} / \mathrm{km}^{2}$ in the Quinault, and $5.0 \pm 1.2 \mathrm{elk} / \mathrm{km}^{2}$ in the Elwha River corridor (Jenkins and Manly, 2008). Those values were proportionally similar to those found in 1985-1986 by Houston et al. (1987), who identified $7.3 \pm 0.8 \mathrm{elk} / \mathrm{km}^{2}$ along the Hoh and $10.8 \pm 1.2 \mathrm{elk} / \mathrm{km}^{2}$ along the Queets River corridor. If channel planform responded strongly to recent elk density, then based on those surveys we should see similar patterns of planform evolution on each river, or perhaps the greatest channel disturbance on the Queets River. Instead, the Hoh River shows a unique, strongly significant braiding increase over recent decades, a trend that cannot be attributed to any denser elk use there compared with the other river corridors. The anomalous width of the Quinault River also cannot be explained by any known historical difference in elk use, as elk abundance and density in the Quinault have been similar to those in the Hoh and less than in the Queets watershed (Jenkins and Manly, 2008).

Rather than inferring gradual recovery from elk overuse in the early 1900 s or channel sensitivity to recent fluctuations in elk abundance, Beschta and Ripple (2008) proposed that abundant elk 80-90 years ago triggered a geomorphic positivefeedback non-recovery response whereby ONP rivers transitioned from single-thread to braided. The Beschta and Ripple conceptual model holds that the rivers have been unnaturally wide and braided, and unnaturally sensitive to flood disturbance, ever since the system 'unraveled' in the early twentieth century, due to long-term elk-browsing effects on black-cottonwood and bigleaf-maple recruitment. Our data did not show a transition from single-thread to braided morphology, but Beschta and Ripple (2008) raised the question of how planform may have changed prior to the aerial photographic record. With sparse geomorphic data from before 1939, can we resolve historical variability well enough by other means to determine whether these rivers widened or became braided before collection of the first aerial photographs, and thus whether high sensitivity to floods is recent and unnatural?

Evaluating this question is complicated by acceleration of glacial retreat in western North America in the 1920s-1940s (Spicer, 1989; Leonard, 1997; Menounos, 2006; Koch et al., 2007; Malcomb and Wiles, 2013). Thus, our study reaches might have experienced simultaneous increases in sediment supply and elk impact at that time. These factors may have made channels wider and more braided shortly before the aerial photographic record began, making it even more difficult to discern geomorphic effects of the wolf-elk trophic cascade.

Accounts from early explorers and settlers are equivocal, in our opinion, as to whether ONP river morphology was fundamentally different in the late 1800s and early 1900s than today. Because early explorers and photographers did not intend to document fluvial geomorphology explicitly, it is seldom clear whether narratives refer to single- or multi-thread channels, or whether oblique historical photographs show the only extant channel or one of several. However, the Press Expedition of 1889-1890 referred to islands and side channels on the Elwha and Quinault Rivers (Wood, 1967), the 1878 Watkinson Expedition mentioned the upper Quinault River having wide gravel bars (Lien, 2001), and 1891-1895 surveys of the Hoh River below our study reach mapped bars and braids (GLO, 1896). Journal entries from the 1890s (published a century later by Morganroth, 1991) described dynamic western Olympic Peninsula rivers with broad gravel bars and channels that 'meander from year to year from one side of [the] banks to the other'. Other early records mention narrow, vegetation-choked channels where, today and in the recent past, a river corridor has substantial unvegetated width (Bountry et al., 2005; Beschta and Ripple, 2008). In rivers as spatially and temporally variable as these, though, a large difference in unvegetated width observed at two long-separated points in time may be real but not indicative of permanent change or robust, long-term trends. Some early photographs also may represent localized observations where a channel was especially difficult to navigate by boat, rather than spatially averaged geomorphic conditions expedition documents and photographs sometimes focused deliberately on the greatest challenges and adventures of the journey. If channels were indeed generally narrow and vegetated around the turn of the twentieth century, the cause may have been a quiescent flood regime, analogous to the early 1970s, but without sufficiently long discharge records it is impossible to be certain. The GLO surveys of 1906-1919 indicated that widths in the study reaches we examined were within the range represented by the aerial photographic record.

If Olympic Peninsula rivers had undergone a major widening and transition to greater braiding over two decades between the start of elk population growth (1910s) and the first aerial photographs (1939), such a geomorphic adjustment 
presumably would have involved substantial erosion, sediment export, and corresponding aggradation in the lower portions of the river corridors as a sediment pulse dispersed (cf. Jacobson and Gran, 1999). The stage-discharge history for the streamgage sites on the four rivers we studied does not show a coherent, substantial stage increase before 1939 to suggest major aggradation. Even though sediment-trapping lakes limit applications of these stage histories on the Quinault River and (after 1927) on the Elwha River, there does not appear to be evidence for a system-wide, major fluvial sediment pulse to support an interpretation of a fundamental geomorphic shift shortly before the start of aerial photography.

Empirically based theories of fluvial geomorphic development strongly suggest that rivers with the attributes of our study reaches on the Hoh, Queets, Quinault, and Elwha Rivers are likely to be braided rather than single-thread. According to empirical slope-discharge threshold criteria (Leopold and Wolman, 1957; Ferguson, 1987; Knighton and Nanson, 1993), for these rivers to be single-thread would require a slope reduction by an order of magnitude or a discharge reduction of 1-2 orders of magnitude (Figure 10). Similarly, formulations for mountain rivers that incorporate bed-sediment grain size as well as discharge or stream power (Van den Berg, 1995; Eaton et al., 2010; Mueller and Pitlick, 2014) imply that our gravelbed reaches would be well above the threshold for braided stream development. Therefore, although we do not know the entire historical range of geomorphic variability, we consider it likely that all of the ONP river reaches we studied were braided or island-braided even prior to the major predatorherbivore disturbances of the early twentieth century.

The broad differences between our inference of physically driven channel evolution and the elk-driven conceptual model of Beschta and Ripple $(2008,2012)$ likely arose from the use of different study designs. Our study was designed to resolve temporal evolution, whereas Beschta and Ripple (2008) emphasized spatial differences - they compared channel planform at one time (the 1990s) among three reaches within ONP and two reaches west of the park boundary. Their study assumed that the major difference between the two groups of reaches was the intensity of elk use, with greater herbivory occurring inside ONP where elk are not hunted by humans. Beschta and Ripple (2008) found wider channels and greater incidence of braiding in the reaches inside ONP, and attributed these characteristics to excessive elk herbivory. We speculate that

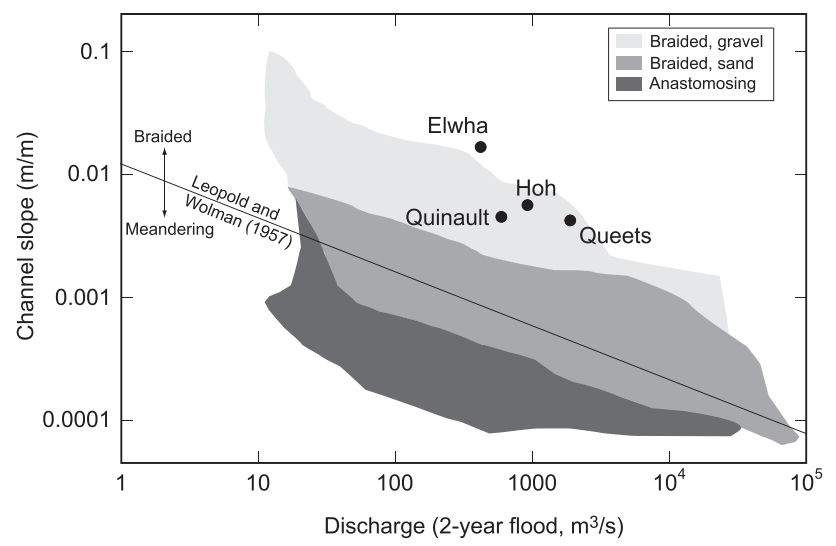

Figure 10. Slope-discharge plot showing the four Olympic National Park study reaches compared with channel patterns defined by previous empirical studies. Gray-shaded regions indicate where most data fall for braided gravel-bed rivers, braided sand-bed rivers, and anastomosing rivers (Ferguson, 1987; Knighton and Nanson, 1993). The Leopold and Wolman (1957) boundary between braided and meandering channels is defined by slope $(s)$ and discharge $(Q)$ such that $s=0.012 \times Q^{-0.44}$ differences in sediment supply and gradient, rather than elk use, may explain the greater width and braiding within ONP (on the Hoh, Queets, and East Fork Quinault Rivers) compared with the Beschta and Ripple (2008) reaches outside ONP (on the Clearwater and lower Quinault Rivers). The Clearwater River does not drain the glaciated, alpine portion of the Olympic Mountains, and thus would carry less sediment than do rivers draining alpine areas (Church and Slaymaker, 1989; Beechie and Imaki, 2014). The lower Quinault River has much lower gradient and sediment supply than reaches upstream from Lake Quinault, which traps sediment and wood (O'Connor et al., 2003; Konrad, 2012). The Quinault River shows an abrupt transition to a less-braided system immediately downstream from the lake.

Although our data indicate that elk impacts on ONP fluvial channel morphology may be subtle enough to be swamped by larger signals of physical controls, we do not discount the key role of herbivores in shaping the structure and composition of ONP riparian forest communities, by means of foraging behavior and food selection. Studies from Yellowstone National Park suggest that elk alter their foraging patterns, including patch selection, group size, and vigilance, when exposed to predation risk (Ripple and Beschta, 2004b; Creel et al., 2005; Fortin et al., 2005; Halofsky and Ripple, 2008). Although ONP elk remain at risk of predation by cougars, the possible alteration of elk-foraging traits after the demise of wolves has not been studied. An explicit, comprehensive test of ecological forcing on channel evolution would require detailed historical data - on predator and prey densities, prey behavior, and vegetation trends - hat do not exist. Thus, studies of this system are limited by inability to determine the full historical range of variability or reference conditions (cf. Stoddard et al., 2006; Wohl, 2011).

Given the pronounced effects of elk herbivory on vegetation recruitment and growth (Houston et al., 1990; Woodward et al., 1994; Ripple and Beschta, 2004a; Painter et al., 2015), and the anomalous age assemblage in ONP of tree species favored as elk browse (Beschta and Ripple, 2008), we cannot rule out some potential influence of elk and vegetation composition on riverbank stability or resilience. In particular, we do not dismiss the possibility that lower elk densities in the presence of wolves could enhance fluvial resilience to physical forcing, through greater cottonwood and bigleaf-maple presence. We cannot determine whether channels would have evolved differently had more cottonwood or bigleaf maple trees been present. Other native, large tree species, such as Sitka spruce (Picea sitchensis) and red alder stems (Alnus rubra), which are relatively unpalatable to elk (Leslie et al., 1984) and dominate riparian forest development after fluvial disturbance (Van Pelt et al., 2006), may substitute for the loss of cottonwood and bigleaf maple in promoting channel stability. We suggest this possibility of functional redundancy in floodplain vegetation as an avenue for future research. However, even the presence of large trees does not guarantee bank stability or resilience to flood erosion, given that channels in this setting with bankfull width $>20 \mathrm{~m}$ also tend to be deep enough that they erode their banks beneath the rooting zone (Beechie et al., 2006), as field observations in our study areas confirm.

If the effects of elk use on ONP fluvial planform are buried in the geomorphic noise, why would this system behave differently from that of Yellowstone National Park (YNP)? There, the wolf-elk trophic-cascade effect on river morphology apparently persists in excessive channel width and local incision, reflecting elk overuse nearly a century after their population peaked. Channel-floodplain hydrologic disconnection remained severe enough after wolf reintroduction that even the flood of record on the Gallatin River, YNP, in 1997 did not inundate floodplain surfaces only modestly higher than 
the active channel (Beschta and Ripple, 2006). We suggest that differences in hydrologic regime and wood availability may explain this disparity between ONP and YNP fluvial geomorphic evolution (note that the gradient of YNP channels such as the Gallatin or Lamar Rivers is similar to our ONP study reaches).

North-coastal rivers in the Pacific Northwest have a winter flood season that features large, abrupt disturbances, including rain-on-snow events that suddenly and dramatically increase river discharge, in contrast to snowmelt-dominated YNP rivers that rarely see flow events departing far from the mean (Figure 11; Poff et al., 2006). Large woody debris is also a much more prominent feature of ONP rivers, promoting channel complexity and new avulsion such that hydrologically disconnecting the channel and floodplain is exceedingly difficult in a wood-rich river. In this respect, ONP rivers also differ from YNP rivers in that the latter depended on beaver dams to maintain water tables and channel-floodplain connectivity (cf. Persico and Meyer, 2009; Polvi and Wohl, 2012), and beaver decline was another component of the wolf-elk trophic cascade in YNP (Ripple and Beschta, 2004a, 2012; Marshall et al., 2013). Beavers tend to be bank-dwellers rather than dam-builders in the disturbanceprone mainstem river corridors of ONP (Knapp, 2009); however, large woody debris in ONP promotes channelfloodplain connectivity even without beaver dams. Sediment-supply differences may also contribute to differences in fluvial form and evolution in ONP compared with YNP, but those are presently unconstrained.
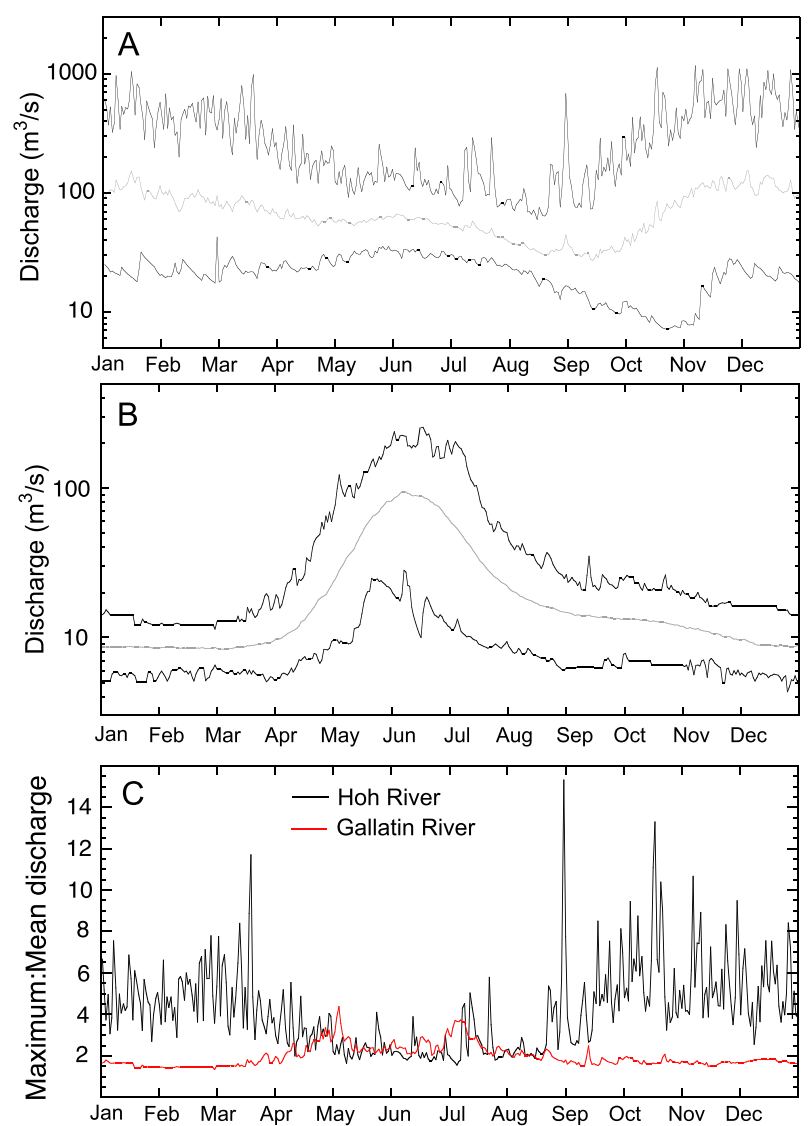

Figure 11. Comparison of flow regime in an Olympic National Park river (Hoh River) and a Yellowstone National Park river (Gallatin River). (A) Hoh River flow envelope, showing daily maximum, mean, and minimum discharge for the period of record at USGS gaging station 12041200 (1961-2014). (B) Gallatin River flow envelope for the period of record at USGS gaging station 06043500, Gallatin River near Gallatin Gateway, Montana (1890-2014). (C) Ratio of maximum to mean discharge values, by year day, for both rivers.
We surmise that even if elk effects alter ONP river morphology over short time scales, within a decade or two a catastrophic flood disturbance - propagated throughout most of the floodplain by wood-induced channel avulsions - will effectively reset the river planform. Abundant rainfall on the Olympic Peninsula then promotes rapid plant growth, facilitating recovery; precipitation there is $\sim 7$ times greater than in YNP, supporting some of the densest forest canopy on Earth (Van Pelt et al., 2006). Thus, trophic-cascade-driven geomorphic perturbations would be overprinted more readily on ONP rivers than in those of the Yellowstone-northern Rocky Mountains region.

However, even in YNP, hydrologic factors can supersede effects of the wolf-elk trophic cascade. Marshall et al. (2013) found that wolf reintroduction and consequent herbivory reduction did little to restore riparian zones if flow and water tables were not also restored to natural conditions. They concluded that predator restoration alone may not reverse the ecological effects of earlier predator loss if hydrology has changed substantially. If wolves were to recolonize Olympic National Park, the complex ecosystem consequences would occur in the context of hydrologic and geomorphic forcing that differs from when wolves were extirpated a century ago, given the likelihood of greater flood intensity and watershed sediment yield.

\section{Future trajectories of ONP rivers}

Future ONP river evolution probably will include additional widening and braiding, due both to an intensified flood regime and to increased sediment supply. The lowermost $22 \mathrm{~km}$ of the Elwha River also will be wider than prior to 2011, due to reservoir-sediment release and restoration of natural upstream sediment supply following two large dam removals (East et al., 2015a; Randle et al., 2015). Predictions of $21^{\text {st }}$-century climatic change for this region include fewer years with large snowpack, more precipitation falling as rain rather than snow in response to cool-season warming, and short-term intense rainfall causing more-frequent winter floods (Jakob and Lambert, 2009; Mantua et al., 2010; Tohver et al., 2014; Lute et al., 2015; Vano et al., 2015). Models show that mid- to high-elevation regions of the Olympic Mountains are especially prone to future increased flooding (Tohver et al., 2014), though presumably these effects would be modulated by annual to interdecadal climate cycles (PDO and El NiñoSouthern Oscillation, ENSO). Additional hydrologic alterations are anticipated from glacial retreat, especially to late-summer streamflow (Riedel et al., 2015).

These climatic and hydrologic changes likely will increase sediment yield, not only from glacier recession but also from landslides (Jakob and Lambert, 2009), although studies of Olympic Mountains landslide frequency had not yet detected such an increase as of the late 1990s and early 2000s (Quinault Indian Nation, 1999; Lyon, 2003). Evaluation of landslide activity as well as further study of fluvial geomorphic changes and sedimentary characteristics, particularly those that could detect sensitivity to glacial recession, would be a valuable means to assess ongoing and future landscape reorganization driven by climate change (cf. Knight and Harrison, 2009; Favaro and Lamoureux, 2015; Singh et al., 2015; Micheletti and Lane, 2016; Schildgen et al., 2016).

\section{Conclusions}

Investigating the relative roles of physical and ecological processes that determine river morphology in four gravel-bed 
rivers of Olympic National Park, Washington, we found that channel planform is driven by hydrologic forcing, and particularly by the recent flood regime. Channel width and braiding on the Hoh, Queets, Quinault, and Elwha Rivers show strong statistical relationships with recent flood magnitude, but not with the recent mean annual flow history. All four rivers have widened significantly in recent decades, consistent with greater flood activity since the 1970s. Channel width and braiding in this setting also respond to sediment-supply changes, including episodic landslide activity. We surmise that recent Hoh River planform change also reflects increased sediment supply associated with rapid glacial retreat; the Hoh River, which drains the majority of the Olympic Mountains ice volume, shows a unique, multi-decadal trend toward greater braiding. Localized legacy effects of anthropogenic modification likely affect the Quinault River planform. The geomorphic changes apparent from a 74-year aerial photographic record demonstrate the particular sensitivity of alpine settings to climate-driven changes. The downstream propagation of climate-driven geomorphic perturbations shows how effectively river systems with high connectivity in the sediment-routing system can transmit environmental signals.

We have found no evidence that greater channel width or braiding correspond to greater elk abundance, suggesting that in this system effects of the wolf-driven trophic cascade are subsidiary to physical controls on channel morphology. Our examinations of stage-discharge history, historical maps, photographs, and descriptions, and empirical geomorphic thresholds do not support a previous conceptual model that these rivers underwent a fundamental geomorphic transition resulting from large elk populations in the early twentieth century. These findings not only differ from previous interpretations of Olympic National Park river dynamics, but also contrast with the classic example of Yellowstone National Park, where legacy effects of abundant elk nearly a century ago apparently still affect channel and floodplain morphology and connectivity. We suggest that the different responses of Olympic and Yellowstone river morphology to trophic-cascade factors are due to differences in hydrologic regime and large-wood availability, such that in coastal Pacific Northwest rivers any signal of elk overuse is more readily overprinted and, on decadal time scales, becomes virtually undetectable in the geomorphic record.

Acknowledgments - This work was funded through a grant from the National Park Service to the US Geological Survey (USGS) to support assessment of natural resource condition in Olympic National Park. The study benefited from valuable discussions with Robert Beschta, William Ripple, Gordon Grant, Josh Latterell, Jim O'Connor, Andy Ritchie, Noah Finnegan, Chris Konrad, Jon Riedel, Mike Miles, and Tim Abbe. We thank Josh Logan for GIS assistance and Patti Haggerty for drafting the map in Figure 1. Andrew Wilcox, Jon Warrick, Christian Torgerson, Rebecca McCaffery, and one anonymous reviewer provided comments that improved the manuscript. We thank the editors for their comments and expertise. Use of trade names is for descriptive purposes only and does not constitute endorsement by the US government.

\section{References}

Abbe TB, Montgomery DR. 1996. Large woody debris jams, channel hydraulics and habitat formation in large rivers. Regulated Rivers: Research \& Management 12: 201-221.

Abbe TB, Montgomery DR. 2003. Patterns and processes of wood debris accumulation in the Queets river basin, Washington. Geomorphology 51: 81-107.

Acker SA, Beechie TJ, Shafroth PB. 2008. Effects of a natural dam-break flood on geomorphology and vegetation on the Elwha River, Washington, USA. Northwest Science 82: 210-223.
Agee JK. 1993. Fire Ecology of Pacific Northwest Forests. Island Press: Washington, DC.

Akaike H. 1974. A new look at the statistical model identification. IEEE Transactions on Automatic Control 19: 716-723.

Allmendinger NE, Pizzuto JE, Potter N, Jr, Johnson TE, Hession WC. 2005. The influence of riparian vegetation on stream width, eastern Pennsylvania. Geological Society of America Bulletin 117: 229-243.

Armitage JJ, Jones TD, Duller RA, Whittaker AC, Allen PA. 2013. Temporal buffering of climate-driven sediment flux cycles by transient catchment response. Earth and Planetary Science Letters 369-370: 200-210.

Ashworth PJ, Best PL, Jones M. 2004. Relationship between sediment supply and avulsion frequency in braided rivers. Geology 32: 21-24.

Bailey V. 1918. Report on investigation of elk herds in the Olympic Mountains, Washington. Unpublished report on file at Olympic National Park, Port Angeles, Washington.

Ballantyne CK, Wilson P, Gheorghiu D, Rodes A. 2014. Enhanced rockslope failure following ice-sheet deglaciation: timing and causes. Earth Surface Processes and Landforms 39: 900-913.

Beechie TJ, Imaki H. 2014. Predicting natural channel patterns based on landscape and geomorphic controls in the Columbia River basin, USA. Water Resources Research 50: 1-19.

Beechie TJ, Liermann M, Pollock MM, Baker S, Davies J. 2006. Channel pattern and river-floodplain dynamics in forested mountain river systems. Geomorphology 78: 124-141.

Beschta RL, Ripple WJ. 2006. River channel dynamics following extirpation of wolves in northwestern Yellowstone National Park, USA. Earth Surface Processes and Landforms 31: 1525-1539.

Beschta RL, Ripple WJ. 2007. Increased willow heights along northern Yellowstone's Blacktail Deer Creek following wolf reintroduction. Western North American Naturalist 67: 613-617.

Beschta RL, Ripple WJ. 2008. Wolves, trophic cascades, and rivers in the Olympic National Park, USA. Ecohydrology 1: 118-130.

Beschta RL, Ripple WJ. 2010. Recovering riparian plant communities with wolves in northern Yellowstone, USA. Restoration Ecology 18 380-389.

Beschta RL, Ripple WJ. 2012. The role of large predators in maintaining riparian plant communities and river morphology. Geomorphology 157-158: 88-98.

Bilby RE, Ward JW. 1991. Characteristics and function of large woody debris in streams draining old-growth, clear-cut, and secondgrowth forests in southwestern Washington. Canadian Journal of Fisheries and Aquatic Science 48: 2499-2508.

Blöthe JH, Korup O. 2013. Millennial lag times in the Himalayan sediment routing system. Earth and Planetary Science Letters 382: 38-46.

Bountry JA, Randle TJ, Piety LA, Lyon EW, Abbe T, Barton C, Ward G, Fetherston K, Armstrong B, Gilbertson L. 2005. Geomorphic Investigation of the Quinault River, Washington. US Department of Interior, Bureau of Reclamation: Denver, CO.

Brandon MT, Roden-Tice MK, Garver JI. 1998. Late Cenozoic exhumation of the Cascadia accretionary wedge in the Olympic Mountains, northwest Washington state. Geological Society of America Bulletin 110: 985-1009.

Brocklehurst SH, Whipple KX. 2002. Glacial erosion and relief production in the Eastern Sierra Nevada, California. Geomorphology 42: $1-24$.

Bureau of Land Management (BLM). 2016. General Land Office cadastral survey archives: http://www.blm.gov/or/landrecords/survey/ ySrvy1.php, accessed 13 January 2016.

Burnham KP, Anderson DR. 2002. Model Selection and Multimodel Interference: a Practical Information-theoretic Approach. Springer: New York.

Cadol D, Rathburn SL, Cooper DJ. 2011. Aerial photographic analysis of channel narrowing and vegetation expansion in Canyon de Chelly National Monument, Arizona, USA, 1935-2004. River Research and Applications 27: 841-856.

Caskey ST, Blaschak TS, Wohl E, Schnackenberg E, Merritt DM, Dwire KA. 2015. Downstream effects of stream flow diversion on channel characteristics and riparian vegetation in the Colorado Rocky Mountains, USA. Earth Surface Processes and Landforms 40: $586-598$

Castelltort S, Van Den Driessche J. 2003. How plausible are highfrequency sediment supply-driven cycles in the stratigraphic record? Sedimentary Geology 157: 3-13. 
Caughley G, Birch LC. 1971. Rate of increase. Journal of Wildlife Management 35: 658-663.

Chien N. 1985. Changes in river regime after the construction of upstream reservoirs. Earth Surface Processes and Landforms 10: 143-159.

Church M. 2010. The trajectory of geomorphology. Progress in Physical Geography 34: 265-286.

Church M, Slaymaker O. 1989. Disequilibrium Holocene sediment yield in glaciated British Columbia. Nature 337: 452-454.

Collins BD, Montgomery DR, Haas AD. 2002. Historical changes in the distribution and functions of large wood in Puget lowland rivers. Canadian Journal of Fisheries and Aquatic Science 59: 66-76.

Collins BD, Montgomery DR, Fetherston KL, Abbe TB. 2012. The floodplain large-wood cycle hypothesis: a mechanism for the physical and biotic structuring of temperate forested alluvial valleys in the North Pacific coastal ecoregion. Geomorphology 139-140: 460-470.

Constantine JA, Dunne T, Ahmed J, Legleiter C, Lazarus ED. 2014. Sediment supply as a driver of river meandering and floodplain evolution in the Amazon Basin. Nature Geoscience 7: 899-903.

Corenblit D, Davies NS, Steiger J, Gibling MR, Bornette G. 2015. Considering river structure and stability in the light of evolution: feedbacks between riparian vegetation and hydrogeomorphology. Earth Surface Processes and Landforms 40: 189-207.

Creel S, Winnie IJ, Maxwell B, Hamlin K, Creel M. 2005. Elk alter habitat selection as an antipredator response to wolves. Ecology 86: 3387-3397.

Czuba JA, Magirl CS, Czuba CR, Johnson KH, Olsen TD, Curran CA, Kimball HK, Gish CC. 2012. Geomorphic analysis of the river response to sedimentation downstream of Mount Rainier. Washington. US Geological Survey Open-File Report: 2012-1242.

Davies M, Hamza O, Harris C. 2001. The effect of rise in mean annual temperature on the stability of rock slopes containing ice-filled discontinuities. Permafrost and Periglacial Processes 12: 137-144.

Draut AE, Logan JB, Mastin MC. 2011. Channel evolution on the dammed Elwha River, Washington, USA. Geomorphology 127: 71-87.

East AE, Pess GR, Bountry JA, Magirl CS, Ritchie AC, Logan JB, Randle TJ, Mastin MC, Minear JT, Duda JJ, Liermann MC, MCHenry ML, Beechie TJ, Shafroth PB. 2015a. Large-scale dam removal on the Elwha River, Washington, USA: river channel and floodplain geomorphic change. Geomorphology 228: 765-786.

East AE, Clift PD, Carter A, Alizai A, VanLaningham S. 2015b. Fluvialeolian interactions in sediment routing and sedimentary signal buffering: an example from the Indus Basin and Thar Desert. Journal of Sedimentary Research 85: 715-728.

Eaton BC, Millar RG, Davidson S. 2010. Channel patterns: braided, anabranching, and single-thread. Geomorphology 120: 353-364.

Egozi R, Ashmore P. 2008. Defining and measuring braiding intensity. Earth Surface Processes and Landforms 33: 2121-2138.

Eisenberg C. 2011. The Wolf's Tooth: Keystone Predators, Trophic Cascades, and Biodiversity. Island Press: Washington, DC.

Estes JA, Tinker MT, Williams TM, Doak DF. 1998. Killer whale predation on sea otters linking oceanic and nearshore ecosystems. Science 282: 473-476.

Estes JA, Terborgh J, Brashares JS, Power ME, Berger J, Bond WJ, Carpeter SR, Essington TE, Holt RD, Jackson JBC, Marquis RJ, Oksanen L, Oksanen T, Paine RT, Pikitch EK, Ripple WJ, Sandin SA, Scheffer M, Schoener TW, Shurin JB, Sinclair ARE, Soule ME, Virtanen R, Wardle DA. 2011. Trophic downgrading of planet earth. Science 333: 301-306.

Everitt B. 1993. Channel responses to declining flow on the Rio Grande between Ft. Quitman and Presidio, Texas. Geomorphology 6: 225-242.

Favaro EA, Lamoureux SF. 2015. Downstream patterns of suspended sediment transport in a High Arctic river influenced by permafrost disturbance and recent climate change. Geomorphology 246: 359-369.

Ferguson RI. 1987. Hydraulic and sedimentary controls of channel pattern. In River Channels: Environment and Process, Richard KS (ed). Blackwell: Oxford; 129-158.

Fetherston KL, Naiman RJ, Bilby RE. 1995. Large woody debris, physical processes, and riparian forest development in montane river networks of the Pacific Northwest. Geomorphology 13: 133-144.

Fortin D, Beyer HL, Boyce MS, Smith DW, Duchesne T, Mao JS. 2005. Wolves influence elk movements: behavior shapes a trophic cascade in Yellowstone National Park. Ecology 86: 1320-1330.
Friend PF, Sinha R. 1993. Braiding and meandering parameters. In Braided Rivers, Best JL, Bristow CS (eds), Vol. 75. Geological Society Special Publication; 105-111.

Fromme RL. 1915. Letter from Forest Supervisor to District Forester, National Archives, on file at Olympic National Park, Port Angeles, Wash.

Gaeuman DA, Schmidt JC, Wilcock PR. 2003. Evaluation of in-channel gravel storage with morphology-based gravel budgets developed from planimetric data. Journal of Geophysical Research-Earth Surface 108 . DOI:10.1029/2002JF000002.F16001

Gendaszek AS, Magirl CS, Czuba CR. 2012. Geomorphic response to flow regulation and channel and floodplain alteration in the gravelbedded Cedar River, Washington, USA. Geomorphology 179: 258-268.

General Land Office (GLO). 1896. Map of Township 27 North, Range 11 West, Willamette Meridian, Washington [surveys made in 18911895]. Map on file at US Department of Agriculture, Bureau of Land Management, Portland, Oregon.

Gerstel WJ, Lingley WS, Jr. 2003. Geologic Map of the Mount Olympus 1:100,000 Quadrangle, Washington. In Open-File Report 2003-4, scale 1:100,000. Wash: Washington Division of Geology and Earth Resources, Olympia.

Godaire JE, Kimbrel S. 2015. Finley Creek alluvial fan geomorphic and hydraulic analyses and implications for restoration. US Bureau of Reclamation, Report prepared for the Quinault Indian Nation and Olympic National Park.

Graf WL. 1978. Fluvial adjustments to the spread of tamarisk in the Colorado Plateau region. Geological Society of America Bulletin 89: 1491-1501.

Gran KB. 2012. Strong seasonality in sand loading and resulting feedbacks on sediment transport, bed texture, and channel planform at Mount Pinatubo, Philippines. Earth Surface Processes and Landforms 37: 1012-1022.

Gran KB, Tal M, Wartman ED. 2015. Co-evolution of riparian vegetation and channel dynamics in an aggrading braided river system, Mount Pinatubo, Philippines. Earth Surface Processes and Landforms 40: $1101-1115$.

Gurnell A. 2014. Plants as river system engineers. Earth Surface Processes and Landforms 39: 4-25.

Halofsky J, Ripple W. 2008. Linkages between wolf presence and aspen recruitment in the Gallatin elk winter range of southwestern Montana, USA. Forestry 81: 195-207.

Hapke CJ, Reid D. 2007. National assessment of shoreline change, part 4-historical coastal cliff retreat along the California Coast. US Geological Survey Open-File Report: 2007-1133.

Happe PJ. 1993. Ecological relationships between cervid herbivory and understory vegetation in old-growth Sitka spruce-western hemlock forests in western Washington. Ph.D. dissertation, Oregon State University: Corvallis, Oregon.

Heitmuller FT. 2014. Channel adjustments to historical disturbances along the lower Brazos and Sabine Rivers, south-central USA. Geomorphology 204: 382-398.

Herrera Environmental Consultants Inc. 2005. Geomorphic assessment of large woody debris, Upper Quinault River. Report prepared for U. S. Bureau of Reclamation and Quinault Indian Nation.

Hoffman DF, Gabet EJ. 2007. Effects of sediment pulses on channel morphology in a gravel-bed river. Geological Society of America Bulletin 119: 116-125.

Houston DB, Moorhead BB, Olson RW. 1987. Roosevelt elk density in old-growth forests of Olympic National Park. Northwest Science 61: 220-225

Houston DB, Schreiner EG, Moorhead BB, Krueger KA. 1990. Elk in Olympic National Park: will they persist over time? Natural Areas Journal 10: 6-11.

Howard AD, Keetch ME, Vincent CL. 1970. Topological and geomorphic properties of braided streams. Water Resources Research 6: 1647-1688.

Hupp CR, Osterkamp WR. 1996. Riparian vegetation and fluvial geomorphic processes. Geomorphology 14: 277-295.

Jacobson RB, Gran KB. 1999. Gravel sediment routing from widespread, low-intensity landscape disturbance, Current River basin, Missouri. Earth Surface Processes and Landforms 24: 897-917.

Jakob M, Lambert S. 2009. Climate change effects on landslides along the southwest coast of British Columbia. Geomorphology 107: 275-284. 
Jefferson County Historical Society. 2010. Images of America: Olympic Mountains. Arcadia Publishing: Charleston, South Carolina.

Jenkins KJ. 1980. Home range and habitat use by Roosevelt elk in Olympic National Park, Washington. MS thesis, Oregon State University, Corvallis, Oregon.

Jenkins KJ, Manly BFJ. 2008. A double-observer method for reducing bias in faecal pellet surveys of forest ungulates. Journal of Applied Ecology 45: 1339-1348.

Jenkins KJ, Starkey EE. 1984. Habitat use by Roosevelt elk in unmanaged forests of the Hoh Valley, Washington. Journal of Wildlife Management 48: 642-646.

Jenkins KJ, Griffin PC, Happe PJ, Reid M, Vales DJ, Moeller BJ, Tirhi M, McCorquodale S, Beirne K, Boetsch J, Baccus W, Lubow B. 2015. Elk monitoring in Mount Rainier and Olympic national parks: 20082011 synthesis report. In Natural Resource Report NPS/NCCN/NRR -2015/904. Fort Collins, CO.: National Park Service.

Kloehn KK, Beechie TJ, Morley SA, Coe HJ, Duda JJ. 2008. Influence of dams on river-floodplain dynamics in the Elwha River, Washington. Northwest Science 82: 224-235.

Knapp RL. 2009. North American beaver (Castor canadensis) habitat use in the Olympic Peninsula's Elwha Valley. MS thesis, Western Washington University, Bellingham.

Knight J, Harrison S. 2009. Sediments and future climate. Nature Geoscience 2: 230.

Knighton AD, Nanson GC. 1993. Anastomosis and the continuum of channel pattern. Earth Surface Processes and Landforms 18: 613-625.

Koch J, Clague JJ, Osborn GD. 2007. Glacier fluctuations during the past millennium in Garibaldi Provincial Park, southern Coast Mountains, British Columbia. Canadian Journal of Earth Sciences 4: 1215-1233.

Kondolf GM, Piegay H, Landon N. 2002. Channel response to increased and decreased bedload supply from land use change; contrasts between two catchments. Geomorphology 45: 35-51.

Konrad CP. 2012. Reoccupation of floodplains by rivers and its relation to the age structure of floodplain vegetation. Journal of Geophysical Research-Earth Surface 117 . DOI:10.1029/2011JG001906.G00N13

Lane SN, Bakker M, Gabbud C, Micheletti N, Saugy JN. in press Sediment export, transient landscape response and catchment-scale connectivity following rapid climate warming and Alpine glacier recession. Geomorphology, dx.doi.org/10.1016/j geomorph.2016.02.015

Latterell JJ, Naiman RJ. 2007. Sources and dynamics of large logs in a temperate floodplain river. Ecological Applications 17: 1127-1141.

Latterell JJ, Bechtold JS, O'Keefe TC, Van Pelt R. 2006. Dynamic patch mosaics and channel movement in an unconfined river valley of the Olympic Mountains. Freshwater Biology 51: 523-544.

Leonard EM. 1997. The relationship between glacial activity and sediment production: evidence from a 4450-year varve record of neoglacial sedimentation in Hector Lake, Alberta, Canada. Journal of Paleolimnology 17: 319-330.

Leopold A. 1949. A Sand County Almanac. Oxford University Press: Oxford.

Leopold LB, Wolman MB. 1957. River channel patterns-braided, meandering and straight. US Geological Survey Professional Paper 282-B.

Leslie DMJ, Starkey EE, Vavra M. 1984. Elk and deer diets in old-growth forests in western Washington. Journal of Wildlife Management 48 $762-775$.

Lien C. 2001. Exploring the Olympic Mountains: Accounts of the Earliest Expeditions, 1878-1890. The Mountaineers Books: Seattle, Washington.

Lovejoy PS. 1911. Letter from Forest Supervisor to District Forester. In National Archives, on file at Olympic National Park. Washington: Port Angeles.

Lute AC, Abatzoglou JT, Hegewisch KC. 2015. Projected changes in snowfall extremes and interannual variability of snowfall in the western United States. Water Resources Research 51: 960-972.

Lyon EW. 2003. Mass wasting in the upper Hoh River watershed, Olympic National Park, Washington, interpreted from 1939 and 2001 aerial photography. US Department of Interior, Bureau of Reclamation, Boise, Idaho.
Madej MA, Ozaki V. 1996. Channel response to sediment wave propagation and movement, Redwood Creek, California, USA. Earth Surface Processes and Landforms 21: 911-927.

Malcomb NL, Wiles GC. 2013. Tree-ring-based reconstruction of North American glacier mass balance through the Little Ice Age - contemporary warming transition. Quaternary Research 79: 123-137.

Mantua NJ, Hare SR, Zhang Y, Wallace JM, Francis RC. 1997. A Pacific interdecadal climate oscillation with impacts on salmon production. Bulletin of the American Meteorological Society 78: 1069-1079.

Mantua N, Tohver I, Hamlet A. 2010. Climate change impacts on streamflow extremes and summertime stream temperature and their possible consequences for freshwater salmon habitat in Washington State. Climatic Change 102: 187-223.

Marren PM, Toomath SC. 2014. Channel pattern of proglacial rivers: topographic forcing due to glacial retreat. Earth Surface Processes and Landforms 39: 943-951.

Marshall KN, Hobbs NT, Cooper DJ. 2013. Stream hydrology limits recovery of riparian ecosystems after wolf reintroduction. Proceedings of the Royal Society B $\mathbf{2 8 0}$.20122977, http://dx.doi.org/10.1098/ rspb.2012.2997

Menounos B. 2006. Anomalous early $20^{\text {th }}$ century sedimentation in proglacial Green Lake, British Columbia, Canada. Canadian Journal of Earth Sciences 43: 671-678.

Menounos B, Clague JJ. 2008. Reconstructing hydro-climate events and glacier fluctuations over the past millennium from annually laminated sediments of Cheakamus Lake, southern Coast Mountains, British Columbia, Canada. Quaternary Science Reviews 27: 701-713.

Micheletti N, Lane SN. 2016. Water yield and sediment export in small, partially glaciated Alpine watersheds in a warming climate. Water Resources Research 52: 4924-4943.

Micheletti N, Lambiel C, Lane SN. 2015. Investigating decadal-scale geomorphic dynamics in an alpine mountain setting. Journal of Geophysical Research-Earth Surface 120: 2155-2175.

Miles M, Allegretto S. 2011. The effects of glacier recession on channel stability and flood hazard: case studies from the Coast Mountains of British Columbia. Abstract, Northwest Regional Floodplain Managers' Association meeting, Bellingham, Washington, Sept. 14-16.

Miller DJ, Benda LE. 2000. Effects of punctuated sediment supply on valley-floor landforms and sediment transport. Geological Society of America Bulletin 112: 1814-1824.

Milliman JD, Farnsworth KL. 2011. River Discharge to the Coastal Ocean-a Global Synthesis. Cambridge University Press.

Montgomery DR, Buffington JM. 1997. Channel-reach morphology in mountain drainage basins. Geological Society of America Bulletin 109: 596-611.

Morganroth C. 1991. Footprints in the Olympics - an Autobiography [journal entries from the 1890s, published a century after their writing by a descendent of the author]. Flaherty KM (ed.). Ye Galleon Press: Fairfield, Washington.

Mueller ER, Pitlick J. 2014. Sediment supply and channel morphology in mountain river systems: 2 . Single thread to braided transitions. Journal of Geophysical Research-Earth Surface 119: 1516-1541.

Murie A. 1935a. Special report of senior naturalist technician Adolph Murie on wildlife of the Olympics. In Unpublished report, on file at Olympic National Park. Washington: Port Angeles.

Murie OJ. 1935b. Report of the elk on the Olympic Peninsula. Unpublished report on file at Olympic National Park, Port Angeles, Washington.

Naiman RJ, Bechtold JS, Beechie TJ, Latterell JJ, Van Pelt R. 2010. A process-based view of floodplain forest patterns in coastal river valleys of the Pacific Northwest. Ecosystems 13: 1-13.

National Park Service. 1937. Recreation statement H.R. 4724. Unpublished report, Mt. Olympus National Monument, 25 February 1937, on file at Olympic National Park, Port Angeles, Washington.

Newman CC. 1954. Special report on the Roosevelt elk of Olympic National Park. Unpublished report, National Park Service, Port Angeles, Washington.

O'Connor JE, Jones MA, Haluska TL. 2003. Flood plain and channel dynamics of the Quinault and Queets Rivers, Washington, USA. Geomorphology 51: 31-59. 
O'Connor JE, Mangano JF, Anderson SW, Wallick JR, Jones KL, Keith MK. 2014. Geologic and physiographic controls on bed-material yield, transport, and channel morphology for alluvial and bedrock rivers, western Oregon. Geological Society of America Bulletin 126: 377-397.

Painter LE, Beschta RL, Larsen EJ, Ripple WJ. 2015. Recovering aspen follow changing elk dynamics in Yellowstone: evidence of a trophic cascade? Ecology 96: 252-263.

Persico L, Meyer G. 2009. Holocene beaver damming, fluvial geomorphology, and climate in Yellowstone National Park, Wyoming. Quaternary Research 71: 340-353.

Phillips JD. 1995. Biogeomorphology and landscape evolution: the problem of scale. Geomorphology 13: 337-347.

Phillips CB, Jerolmack DJ. 2016. Self-organization of river channels as a critical filter on climate signals. Science 352: 694-697.

Piety LA, Bountry JA, Randle TJ, Lyon EW. 2004. Summary report for geomorphic assessment of Hoh River in Washington state: river mile 17 to 40 between Oxbow Canyon and Mount Tom Creek. US Department of Interior, Bureau of Reclamation, Denver, CO.

Podolak CJP, Wilcock PR. 2013. Experimental study of the response of a gravel streambed to increased sediment supply. Earth Surface Processes and Landforms 38: 1748-1764.

Poff NL, Bledsoe BP, Cuhaciyan CO. 2006. Hydrologic variation with land use across the contiguous United States: geomorphic and ecological consequences for stream ecosystems. Geomorphology 79: 264-285.

Polvi LE, Wohl E. 2012. The beaver meadow complex revisited-the role of beavers in post-glacial floodplain development. Earth Surface Processes and Landforms 37: 332-346.

Praskievicz S. 2015. A coupled hierarchical modeling approach to simulating the geomorphic response of river systems to anthropogenic climate change. Earth Surface Processes and Landforms 40: 1616-1630.

PRISM. 2016. PRISM Climate group data portal, Oregon State University, http://www.prism.oregonstate.edu, last accessed 25 January 2016

Prugh LR, Stoner CJ, Epps CW, Bean WT, Ripple WJ, Laliberte AS, Brashares JS. 2009. The rise of the mesopredator. Bioscience 59: 779-791.

Quinault Indian Nation. 1999. Quinault River watershed analysis. In Report prepared by Quinault Indian Nation, Olympic National Forest, US Department of Agriculture-Forest Service, and US Geological Survey. Washington: Taholah.

Raedeke KJ, Taber RD. 1982. Mechanisms of population regulation in western Washington forests for Cervus and Odocoileus. Transactions of the International Congress of Game Biologists 14: 69-79.

Randle TJ, Bountry JA, Ritchie A, Willie K. 2015. Large-scale dam removal on the Elwha River, Washington: erosion of reservoir sediment. Geomorphology 246: 709-728.

Rasmussen LA, Conway H. 2001. Estimating South Cascade Glacier (Washington, USA) mass balance from a distant radio-sonde and comparison with Blue Glacier. Journal of Glaciology 47: 579-588.

Reinhardt L, Jerolmack D, Cardinale BJ, Vanacker V, Wright J. 2010. Dynamic interactions of life and its landscape: feedbacks at the interface of geomorphology and ecology. Earth Surface Processes and Landforms 35: 78-101.

Rhoads BL, Lewis QW, Andresen W. 2016. Historical changes in channel network extent and channel planform in an intensively managed landscape: natural vs. human-induced effects. Geomorphology 252: $17-31$.

Riedel JL, Wilson S, Baccus W, Larrabee M, Fudge TJ, Fountain A. 2015. Glacier status and contribution to streamflow in the Olympic Mountains, Washington, USA. Journal of Glaciology 61: 8-16.

Rinaldi M. 2003. Recent channel adjustments in alluvial rivers of Tuscany, central Italy. Earth Surface Processes and Landforms 28: 587-608.

Ripple WJ, Beschta RL. 2004a. Wolves, elk, willows, and trophic cascades in the upper Gallatin Range of southwestern Montana, USA. Forest Ecology and Management 200: 161-181.

Ripple WJ, Beschta RL. 2004b. Wolves and the ecology of fear: can predation risk structure systems? BioScience 54: 755-766.

Ripple WJ, Beschta RL. 2012. Trophic cascades in Yellowstone: the first 15 years after wolf reintroduction. Biological Conservation 145: 205-213.

Sankey JB, Ralston BE, Grams PE, Schmidt JC, Cagney LE. 2015. Riparian vegetation, Colorado River, and climate: five decades of spatiotemporal dynamics in the Grand Canyon with river regulation. Journal of Geophysical Research-. Biogeosciences 120: 1532-1547. Scheffer VV. 1995. Mammals of the Olympic National Park and vicinity (1949). Northwest fauna occasional monographs on vertebrate natural history 2.

Schiefer E, Hassan MA, Menounos B, Pelpola CP, Slaymaker O. 2010. Interdecadal patterns of total sediment yield from a montane catchment, southern Coast Mountains, British Columbia, Canada. Geomorphology 118: 207-212.

Schildgen TF, Robinson RAJ, Savi S, Phillips WM, Spencer JQG, Bookhagen B, Scherler D, Tofelde S, Alonso RN, Kubik PW, Binnie SA, Strecker MR. 2016. Landscape response to late Pleistocene climate change in NW Argentina: sediment flux modulated by basin geometry and connectivity. Journal of Geophysical Research-Earth Surface 121: 392-414.

Schmitz OJ, Hambäck PA, Beckerman AP. 2000. Trophic cascades in terrestrial ecosystems: a review of the effects of carnivore removals on plants. American Naturalist 155: 141-153.

Schreiner EG, Krueger KA, Happe PJ, Houston DB. 1996. Understory patch dynamics and ungulate herbivory in old-growth forests of Olympic National Park, Washington. Canadian Journal of Forest Research 26: 255-265.

Schroer GL, Jenkins KJ, Moorhead BB. 1993. Roosevelt elk selection of temperate rain forest seral stages in western Washington. Northwest Science 67: 23-29.

Schumm SA. 1985. Patterns of alluvial rivers. Annual Reviews of Earth and. Planetary Science 13: 5-27.

Schwartz JE. 1939. The Olympic elk study. In Unpublished report, US Forest Service, Olympia, Washington, on file at Olympic National Park. Washington: Port Angeles.

Sear DA, Newson MD, Brookes A. 1995. Sediment-related river maintenance: the role of fluvial geomorphology. Earth Surface Processes and Landforms 20: 629-647.

Simon A. 1999. Channel and drainage-basin response of the Toutle River system in the aftermath of the 1980 eruption of Mount St. Helens, Washington. US Geological Survey Open-File Report 96633.

Simon A, Thomas RE, Curini A, Shields FDJ. 2002. Case study—channel stability of the Missouri River, eastern Montana. Journal of $\mathrm{Hy}$ draulic Engineering 128: 880-890.

Simpson G, Castelltort S. 2012. Model shows that rivers transmit highfrequency climate cycles to the sedimentary record. Geology 40: 1131-1134.

Singh A, Reinhardt L, Foufoula-Georgiou E. 2015. Landscape reorganization under changing climatic forcing - results from an experimental landscape. Water Resources Research 51: 4320-4337.

Skinner MP. 1933. Report on Roosevelt elk, Olympic Peninsula, Washington. Unpublished report, National Park Service, Port Angeles, Washington.

Smith ND, Smith D. 1984. William River; an outstanding example of channel widening and braiding caused by bed-load addition. Geology 12: 78-82.

Spicer RC. 1989. Recent variations of Blue Glacier, Olympic Mountains, Washington, USA. Arctic and Alpine Research 21: 1-21.

Stewart RJ, Brandon MT. 2004. Detrital-zircon fission-track ages for the "Hoh Formation": implications for late Cenozoic evolution of the Cascadia subduction wedge. Geological Society of America Bulletin 116: 60-75.

Stoddard JL, Larsen DP, Hawkins CP, Johnson RK, Norris RH. 2006. Setting expectations for the ecological condition of streams: the concept of reference condition. Ecological Applications 16: 1267-1276.

Sumner EL. 1938. Special report of elk in Olympic National Park. US Department of Interior, National Park Service, San Francisco, CA.

Swanson FJ, Lienkaemper GW. 1982. Interactions among fluvial processes, forest vegetation, and aquatic ecosystems, South Fork Hoh River, Olympic National Park. In Ecological Research in National Parks of the Pacific Northwest, Starkey EE, Franklin JF, Matthew JW (eds) . Oregon State University Forest Research Laboratory: Corvallis, Oregon; 30-34.Proceedings of the 2nd Conference on Scientific Research in the National Parks, November 1979, San Francisco, CA

Tabor RW. 1987. Geology of Olympic National Park: Pacific Northwest National Parks and Forests Association, Seattle, Washington. 
Tabor RW, Cady WM. 1978. Geologic map of the Olympic Peninsula, Washington. In US Geological Survey Miscellaneous Investigations Series Map 1-944, 2 sheets, scale 1:125,000. Virginia: Reston.

Tal M, Gran K, Murray AB, Paola C, Hicks DM. 2004. Riparian vegetation as a primary control on channel characteristics in multi-thread rivers. Water Science and Application 8: 43-57.

Terborgh J, Lopez L, Nuñez PV, Rao M, Shahabuddin G, Orihuela G, Riveros M, Ascanio R, Adler GH, Lambert TD, Balbas L. 2001. Ecological meltdown in predator-free forest fragments. Science 294: 1923-1926.

Tohver IM, Hamlet AF, Lee SY. 2014. Impacts of $21^{\text {st }}$-century climate change on hydrologic extremes in the Pacific Northwest region of North America. Journal of the American Water Resources Association 50: $1461-1476$.

US Department of Agriculture. 2013. National Agricultural Imaging Project aerial photography: https://gdg.sc.egov.usda.gov/

US Geological Survey. 1981. Guidelines for determining flood flow frequency. Bulletin \#17B of the Hydrology Subcommittee, Interagency Advisory Committee on Water Data. U.S. Geological Survey; 194 pp., http://water.usgs.gov/osw/bulletin17b/bulletin_17B.html

Van Den Berg Van Saparoea APH, Postma G. 2008. Control of climate change on the yield of river systems. Recent advances in models of siliciclastic shallow-marine stratigraphy: SEPM Special Publication 90: 15-33.

Van den Berg JH. 1995. Prediction of alluvial channel pattern of perennial rivers. Geomorphology 12: 259-279.
Van Pelt R, O'Keefe TC, Latterell JJ, Naiman RJ. 2006. Riparian forest stand development along the Queets River in Olympic National Park, Washington. Ecological Monographs 76: 277-298.

Vano JA, Nijssen B, Lettenmaier DP. 2015. Seasonal hydrologic responses to climate change in the Pacific Northwest. Water Resources Research 51: 1959-1976.

Washington State Library. 2015. North Olympic Heritage Project, Kellogg Collection of historical photographs, available online at: http://www.washingtonruralheritage.org/cdm/search/collection/nols/ searchterm/river/order/nosort, last accessed 30 December, 2015.

Wohl E. 2011. What should these rivers look like? Historical range of variability and human impacts in the Colorado Front Range, USA. Earth Surface Processes and Landforms 36: 1378-1390.

Wohl E. 2013. Floodplains and wood. Earth-Science Reviews 123: 194-212.

Wood RL. 1967. Across the Olympic Mountains - the Press Expedition, 1889-1890, 2nd edn. The Mountaineers Books: Seattle, Washington. Woodward A, Schreiner EG, Houston DB. 1994. Ungulate forest relationships in Olympic National Park: retrospective exclosure studies. Northwest Science 68: 97-110.

\section{Supporting Information}

Additional supporting information may be found in the online version of this article at the publisher's web site. 